\title{
Subsurface structure of the Netherlands - results of recent onshore and offshore mapping
}

\section{E.J.T. Duin, J.C. Doornenbal, R.H.B. Rijkers ${ }^{*}$, J.W. Verbeek \& Th.E. Wong}

TN0 Built Environment and Geosciences - Geological Survey of the Netherlands, P.0. Box 80015, 3508 TA Utrecht, the Netherlands.

* Corresponding author. Email: richard.rijkers@tno.nl

Manuscript received: September 2006; accepted November 2006

\begin{abstract}
This paper presents depth maps for eight key horizons and seven thickness maps covering the onshore and offshore areas for the Late Permian to recent sedimentary section of the Netherlands. These maps, prepared in the context of a TN0 regional mapping project, are supported by nine regional structural cross sections and a table summarizing the timing of tectonic activity from Carboniferous to recent. These new regional maps enable the delineation of various structural elements but also reveal the development of these elements through time with improved detail. Since the latest Carboniferous the tectonic setting of the Netherlands changed repeatedly. During successive tectonic phases several pre-existing structural elements were reactivated and new elements appeared. The various identified regional structural elements are grouped into six tectonically active periods: Late Carboniferous, Permian, Triassic, Late Jurassic, Late Cretaceous and Cenozoic. This study demonstrates that many structural elements and fault systems were repeatedly reactivated and that a clear distinction exists between long-lived elements, such as the Roer Valley Graben, and short-lived structural elements, such as the Terschelling Basin.
\end{abstract}

Keywords: geological maps, structural elements, Permian, Triassic, Jurassic, Cretaceous, Cenozoic, Netherlands

\section{Introduction}

This paper presents the results of a regional geological mapping project of the Dutch onshore and offshore subsurface at a scale of $1: 2,500,000$ that was carried out by TNO at the request of the Ministry of Economical Affairs with the following objectives:

- to promote exploration efforts in the Netherlands;

- to obtain a regional framework for a detailed geological mapping program 2006 - 2010;

- to enhance research for the use of the subsurface for $\mathrm{CO}_{2}$ storage and geothermal energy production.

The onshore part of the maps presented, was recently published in the Geological Atlas of the Subsurface of the Netherlands - onshore (TNO-NITG, 2004), while the offshore part is being published for the first time. In this paper we present these new integrated maps and cross sections and briefly discuss the main regional structural elements.
Depth and thickness maps have been created for the Zechstein Group (Late Permian), the Lower and Upper Germanic Trias groups, the Altena Group (Early and Middle Jurassic), the Schieland-Scruff-Niedersachsen groups (Late Jurassic), the Rijnland Group (Early Cretaceous), the Chalk Group (Late Cretaceous), the Lower and Middle North Sea groups (Paleogene) and the Upper North Sea Group (Neogene) (Fig. 1). These maps provide an overview of the geological development of the deep subsurface of the Netherlands since the Carboniferous. In this paper the presented maps are discussed in two paragraphs for each lithostratigraphic group by describing (a) depth, thickness and basin development and (b) structural development (faults, erosion and salt movements).

Figure 1 shows the geological time scale of Gradstein et al. (2004) together with the mapped lithostratigraphic intervals that are discussed in this paper. For detailed information on the lithostratigraphy of the mapped intervals and a discussion on regional structural elements readers are referred to earlier publications by TNO-NITG (2004) and Van Adrichem Boogaert 


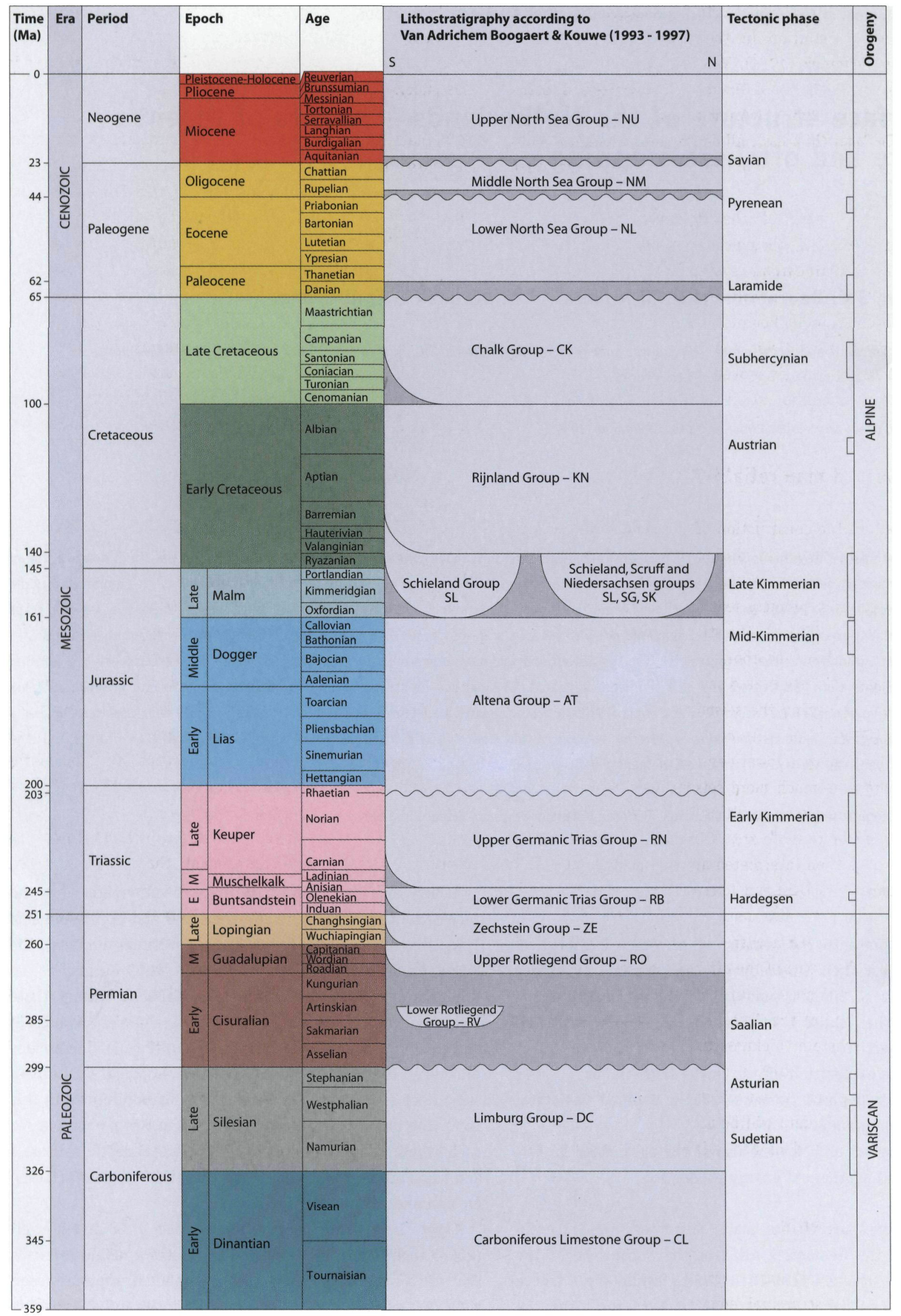

Fig. 1. Geological time scale (after Gradstein et al, 2004) and lithostratigraphic column (after Van Adrichem Boogaert \& Kouwe, 1993 - 1997) showing main tectonic deformation phases. 
\& Kouwe (1993 - 1997). Earlier structural geological models and studies of basin evolution in the Netherlands have been published by Heybroek (1974), Van Wijhe (1987), Rijkers \& Duin (1994), Racero-Baena \& Drake (1996), Rijkers \& Geluk (1996), Dirkzwager (2002), Wórum (2004), Van Balen et al. (2005) and De Jager (in press). All depth maps, thickness maps and figures that are presented in this paper can be downloaded from www.nlog.nl.

Further improvement of the structural reconstruction is necessary to explain geological distribution of aquifers, reservoirs and hydrocarbon systems. In particular the reconstruction and timing of salt tectonics in the Netherlands can be improved strongly. Regional maps are also required for analysis of paleo-stress fields and timing of salt movement and contribute to an improved understanding of fault patterns, reservoir configuration and burial evolution on a local scale.

\section{Data base and map reliability}

The data used for the construction of the maps were acquired from various oil companies during their exploration and production activities since the beginning of the 20th century. For this project, only publicly released seismic and borehole data have been used (Fig. 2). The stratigraphic information of 1756 boreholes has been incorporated in the interpretation of the seismic data. The interpreted seismic data were converted from time to depth using the seismic velocity model of Van Dalfsen et al. (this volume). In contrast to the onshore area, the offshore part shows a lower density of used seismic lines. In the onshore area much more seismic data were available than in the offshore region resulting in a higher reliability of the map data in the onshore area. Offshore areas in which 3D seismic data have been interpreted are the Cleaver Bank High ( $\mathrm{CBH})$, Ameland Block (AB) and Terschelling Basin (TB) (Figs 2 and $4 \mathrm{~d}$ ). In these areas the maps show more detail and are more reliable than the areas with a low coverage of $2 \mathrm{D}$ seismic data. In the southern part of the offshore region the thickness map of the Zechstein Group is largely based on well data. In this area, the depth map of the Zechstein Group was constructed by adding the Zechstein thickness to the Triassic depth map. For the period 2006 - 2010, a detailed geological mapping project is programmed during which more recently released (3D) seismic and well data will be accessed, which will result in the improvement and higher reliability of the depth and thickness maps.

\section{Structural elements}

Nine regional geological cross sections were constructed to illustrate the main structural elements of the Netherlands (Fig. 3). In this paper the term 'structural element' is given to regional structures with a uniform deformation history in terms of subsidence, faulting, uplift and erosion during a specific time interval. The structural element maps have been reconstructed from the depth and thickness maps presented in this paper. In order to map these regional structural elements systematically, the following structural types are used: basin, high, platform and fault (-zone). The boundaries of structural elements, including basins, are delineated by subcrops, (major) faults or salt structures. In this study a high is defined as an area with significant erosion down into Carboniferous or Permian strata (Rotliegend and/or Zechstein). A platform is characterized by Late Jurassic erosion into the Triassic and the absence of Lower and Upper Jurassic strata. The term graben is used for subsided structural elements that are clearly delineated by major linear faulting. Exceptions on this systematical methodology in nomenclature of structural elements are the Ems Low (EL), Lauwerszee Trough (LT), Netherlands Swell (NS) and Zandvoort Ridge (ZR). These names are not changed because of their common use in literature.

The regional structural elements have been reconstructed for six tectono-stratigraphic periods, namely Late Carboniferous Early Permian (Variscan phases), Middle and Late Permian, Triassic (Early Kimmerian phase), Late Jurassic (Late Kimmerian phase), Late Cretaceous (Subhercynian phase) and Cenozoic (Laramide, Pyrenean and Savian phases) (Figs 4a - 4f). Improved delineation of basin structures is obtained by using the subcrops of the Lower and Upper Jurassic strata. Table 1a indicates the active geological period for each structural element with regional significance that is recognized in these new maps. Major fault zones that are indicated in the deformation scheme in Table $1 \mathrm{a}$ are recognized both in the maps and the cross sections. In Table $1 \mathrm{~b}$ the geological description and the used abbreviations of these main structural elements are given. It is strongly recommended not to mingle names of structural elements that have been active during different geological periods. For instance, the larger part of the Mid North Sea High (MNSH) is a Variscan structure, while the Elbow Spit High (ESH), at more or less the same location, is of Late Jurassic origin (Figs $4 \mathrm{a}$ and d).

The structural grain has been strongly influenced by fault systems in the basement that came into existence during the Variscan orogeny (Late Carboniferous - Permian phases). It is obvious from the structural element maps that the Late Jurassic - Early Cretaceous extensional tectonics dominates the structural configuration of the Dutch subsurface, involving Kimmerian reactivation of pre-existing Permo-Carboniferous faults. Late Jurassic and Early Cretaceous subsidence of basins and uplift of flanking platforms, combined with effects of salt movement, reflect the development of a complex structural setting. The geological setting during the Late Jurassic was characterized by erosion of elevated platforms together with the accumulation of sediment in the local basins along the edges of the uplifted blocks. It is emphasized that Late Jurassic depositional areas are relatively small as compared to 


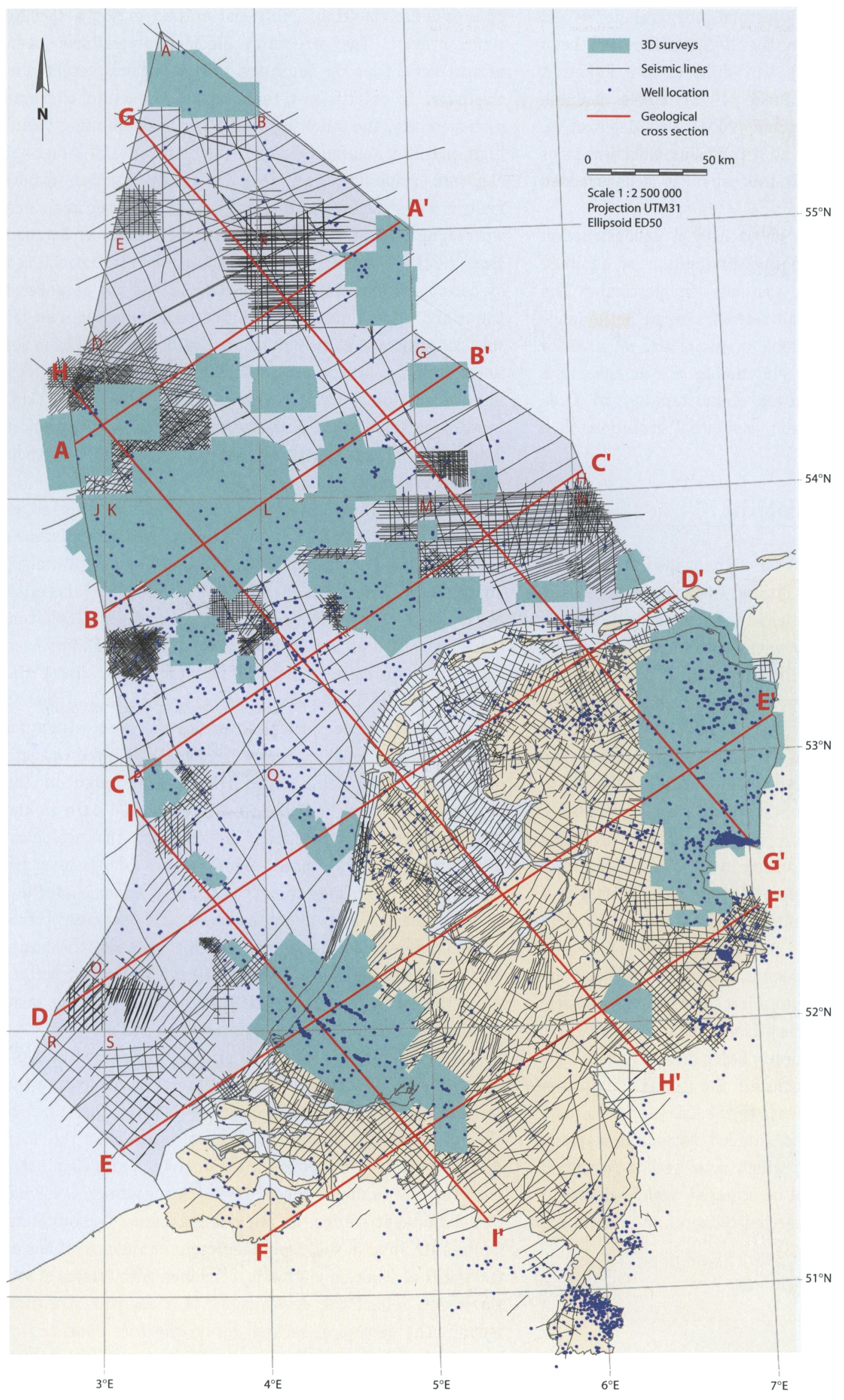

Fig. 2. Map showing the locations of seismic lines and wells used, and geological cross sections given in Fig. 3 . 


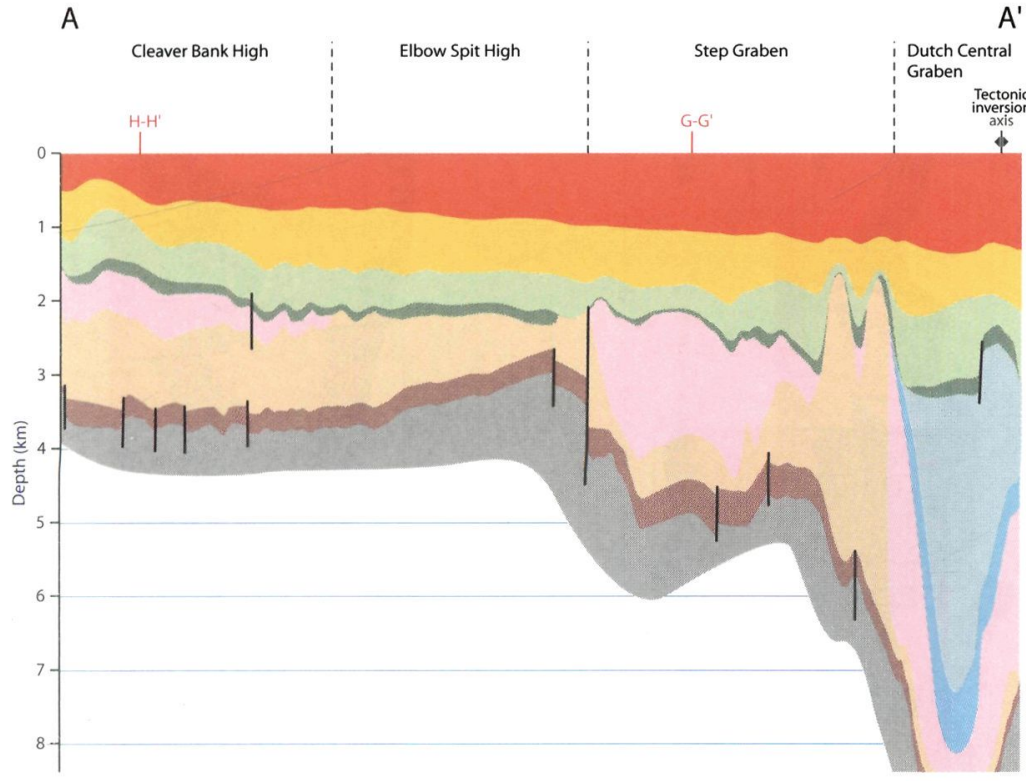

B

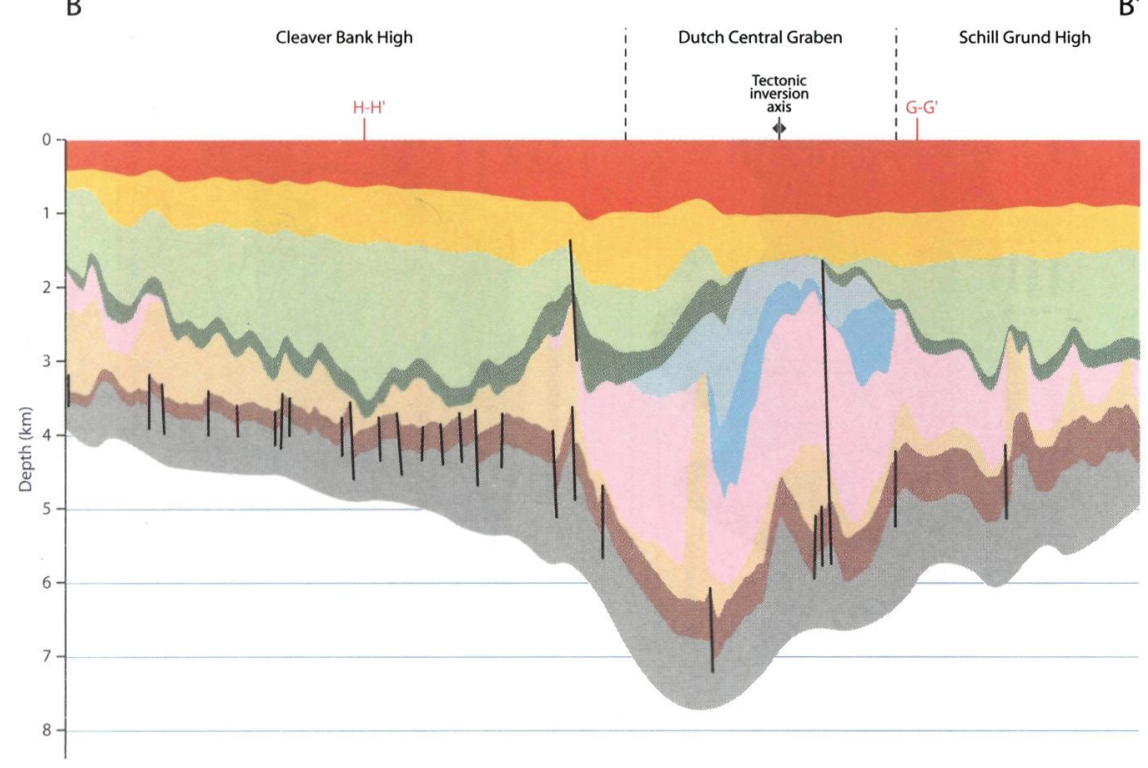

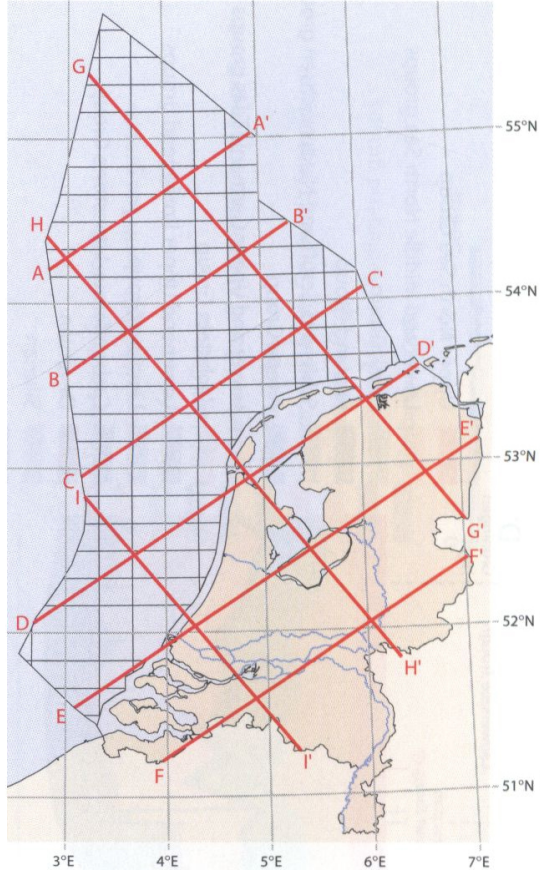

Upper North Sea Group Lower and Middle North Sea groups Chalk Group Rijnland Group Schieland, Scruff and Niedersachsen groups Altena Group

Lower and Upper Germanic Trias groups Zechstein Group

Lner and Upper Rotliegend groups Limburg Group $50 \mathrm{~km}$

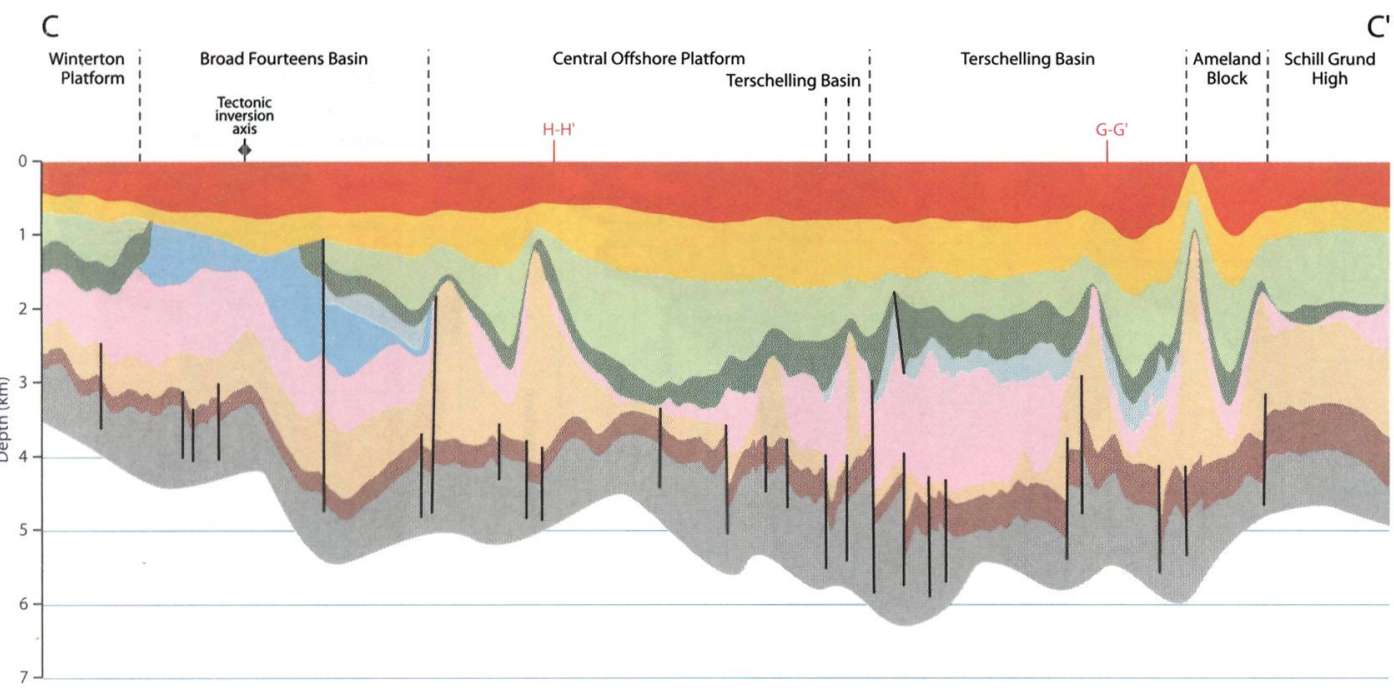

Fig. 3a. SW-NE geological cross sections $A-A^{\prime}, B-B^{\prime}$ and $C-C^{\prime}$. 


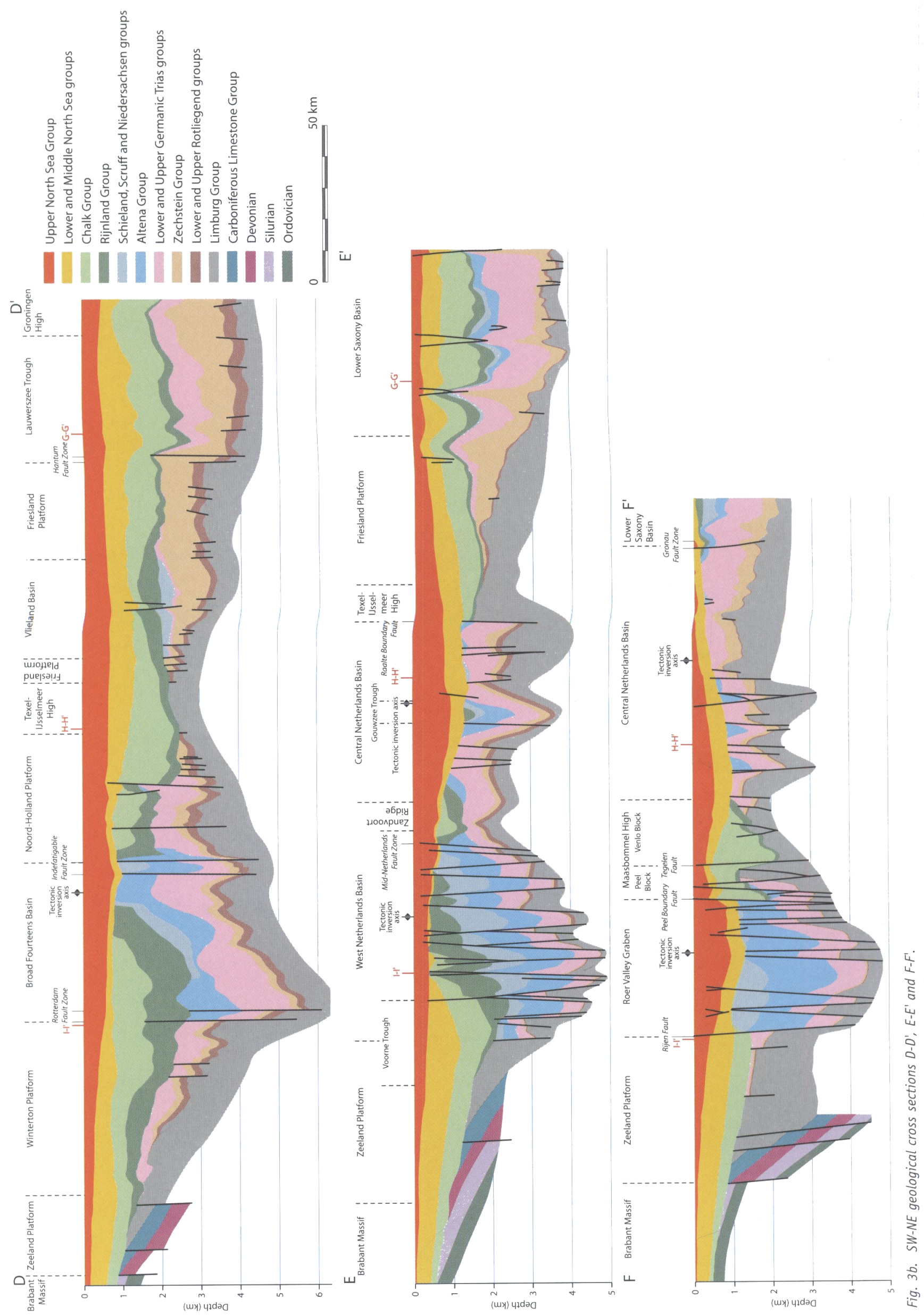




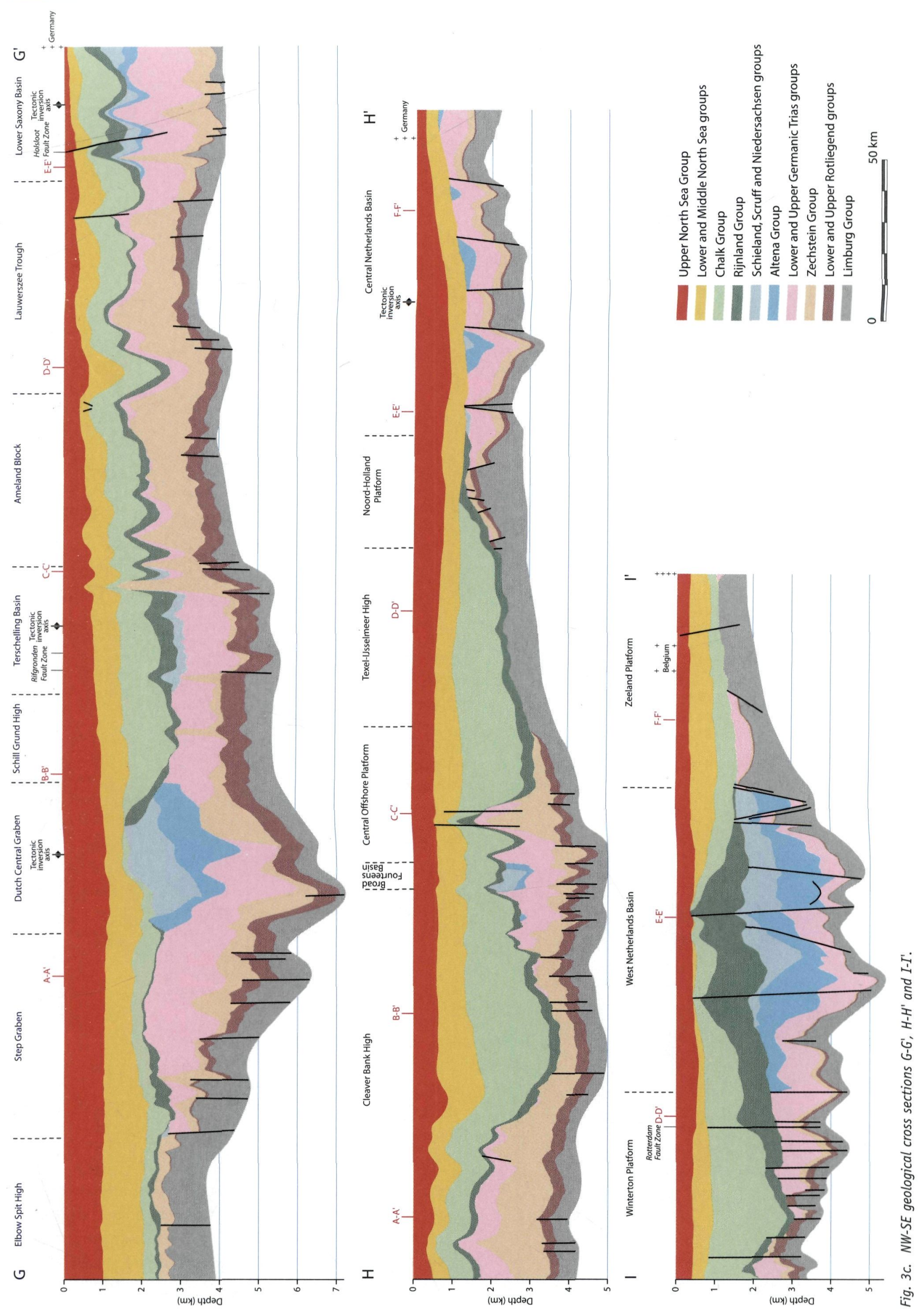

Netherlands Journal of Geosciences - Geologie en Mijnbouw | 85-4|2006 


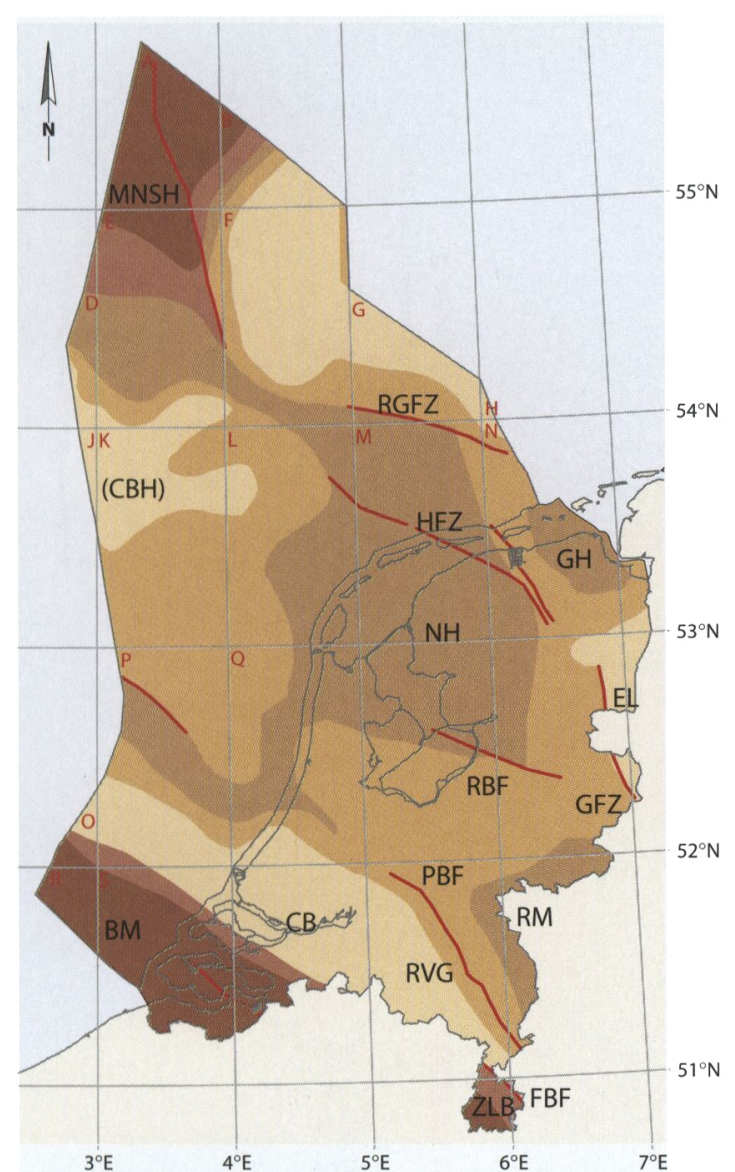

a. Variscan structural elements

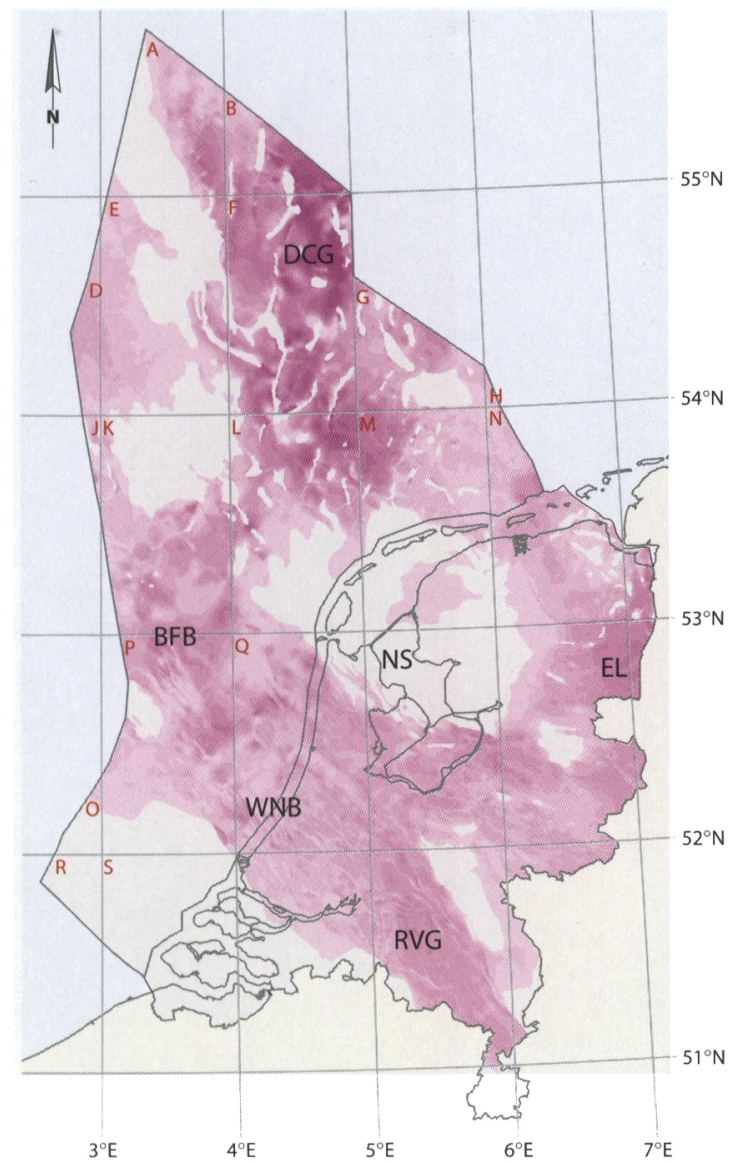

c. Triassic structural elements (Early Kimmerian phase)

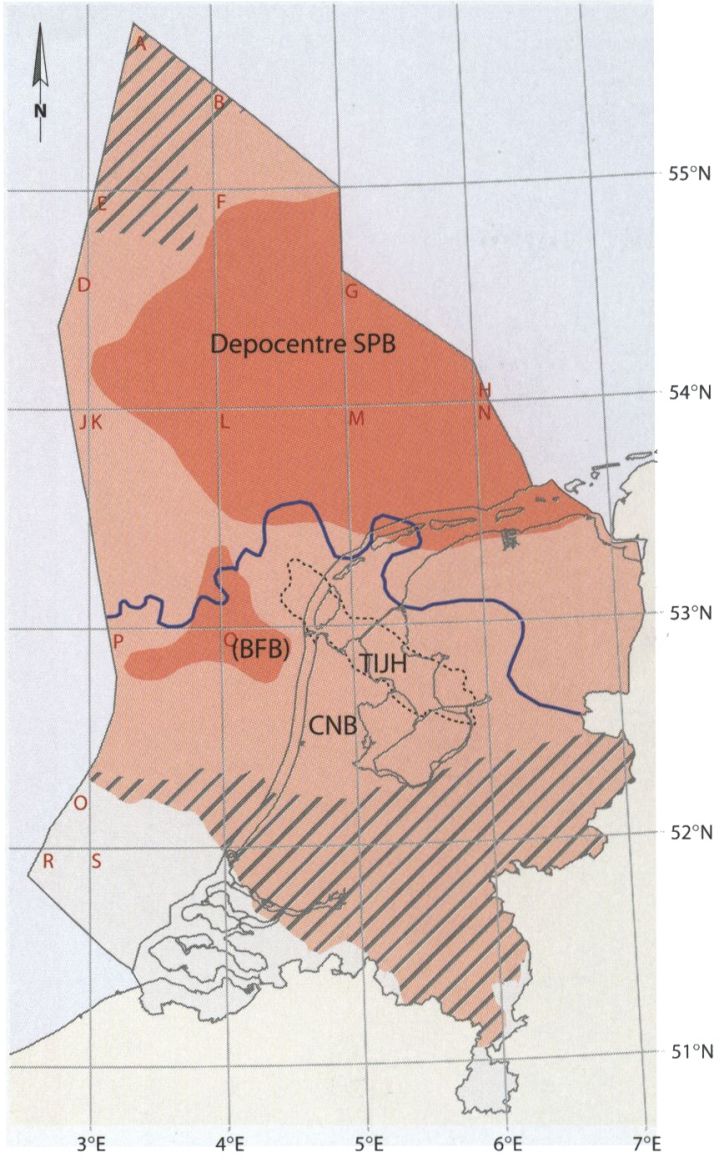

b. Late Permian structural elements

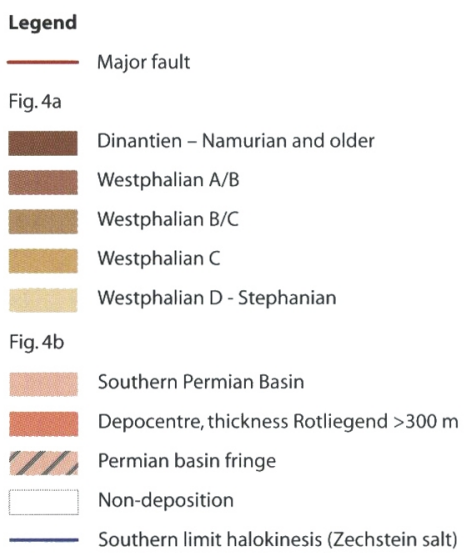

Fig. 4c

Thickness of Triassic deposits in $\mathrm{m}$

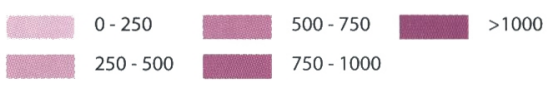

Triassic deposits absent by erosion or non-deposition

Scale 1:5000 000

Projection UTM3

Ellipsoid ED50

Fig. 4 Structural element maps $(1: 5000000)$ summarizing main structural features active during the six tectono-stratigraphic periods $(4 a-4 f)$. The structural elements are mainly based on the present-day thickness maps in Figs 5 - 12. For explanation of the abbreviations of the structural elements and the faults see Table 1. 

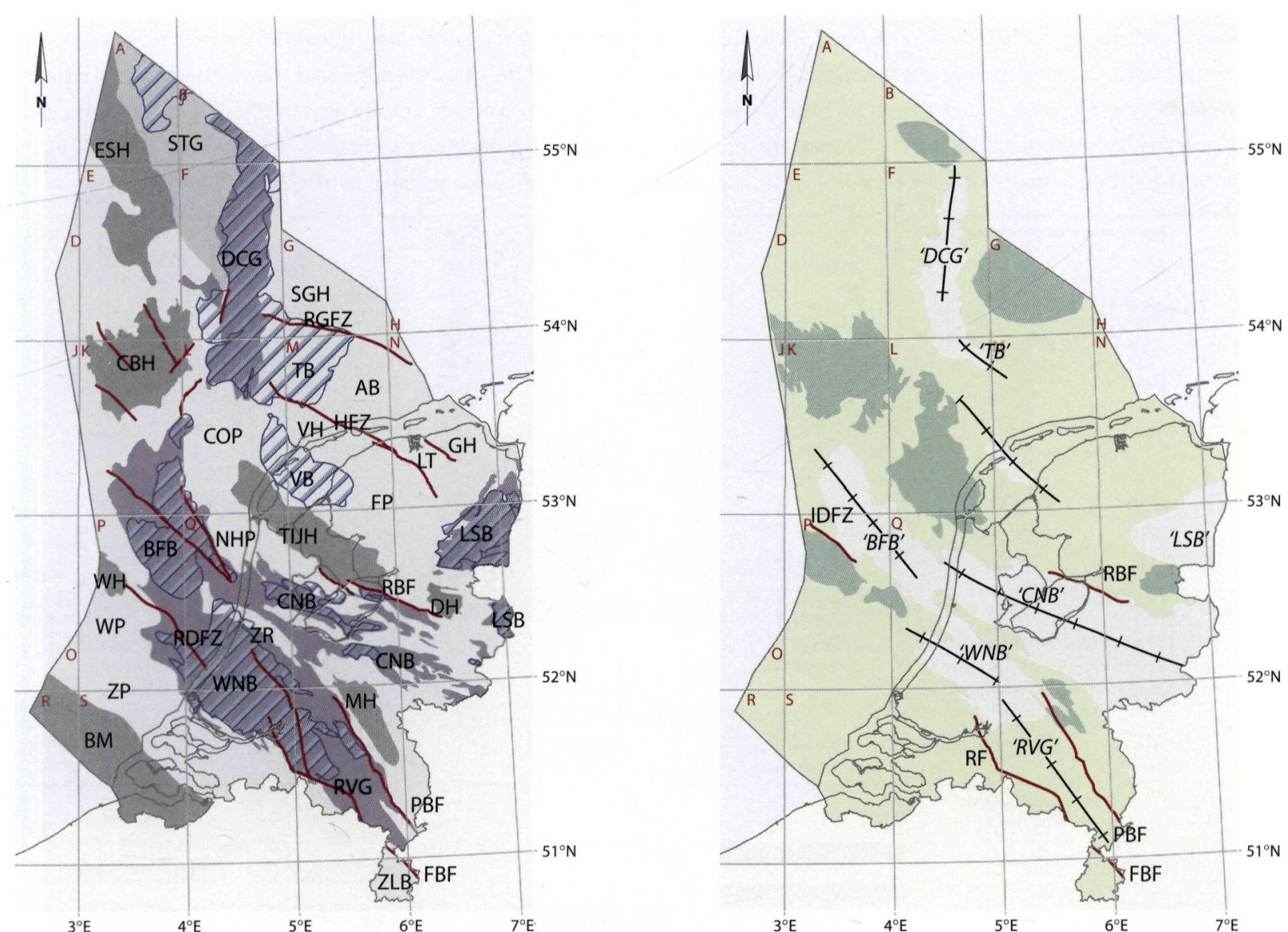

d. Late Jurassic - Early Cretaceous structural elements (Late Kimmerian phases)

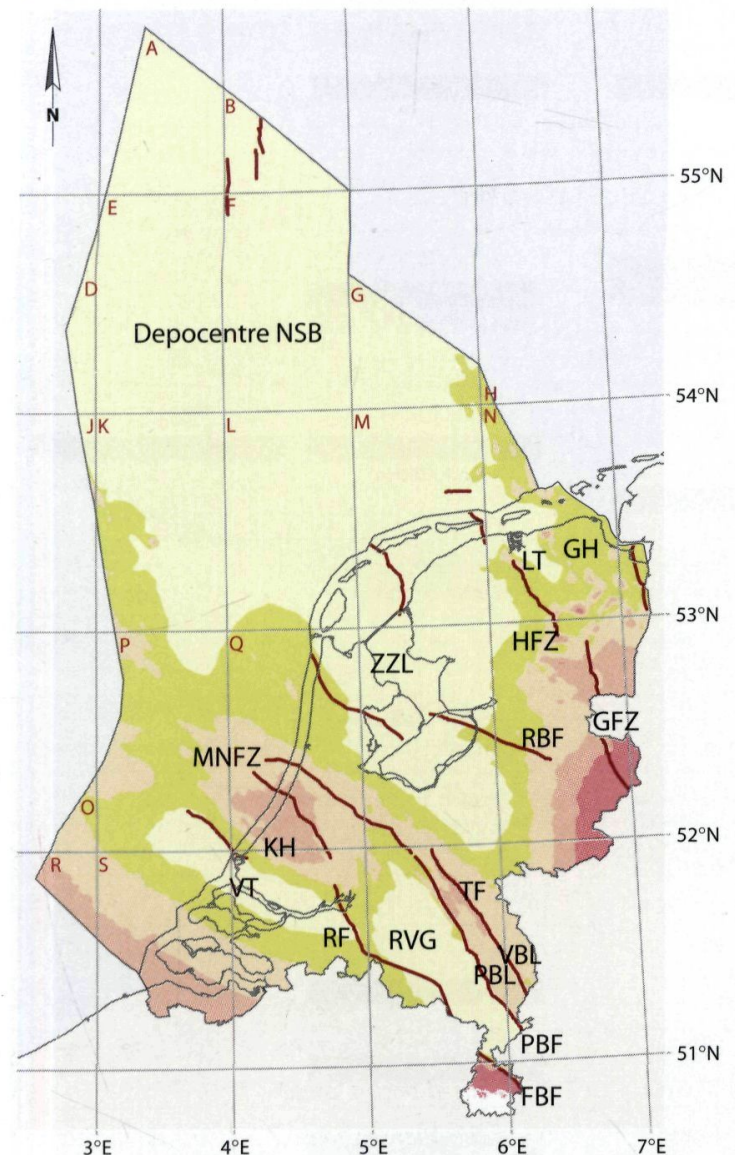

e. Late Cretaceous-Early Tertiary structural elements and basins (Subhercynian and Laramide phases)

Legend

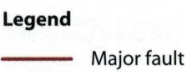

Fig. $4 d$

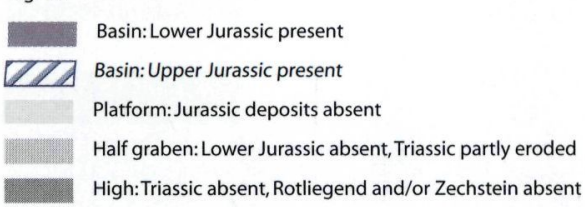

Fig. 4 e

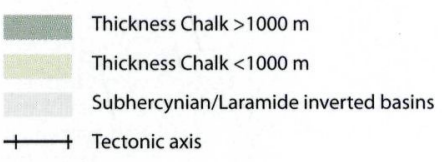

Fig. $4 f$

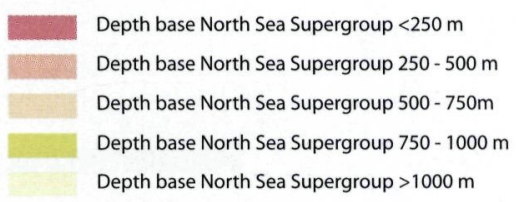
$100 \mathrm{~km}$

Scale $1: 5000000$

Projection UTM31

Ellipsoid ED50

f. Cenozoic structural elements (Pyrenean and Savian phases) 
Table 1a. Deformation scheme of regional structural elements in the subsurface of the Netherlands onshore and offshore. The scheme indicates for each structural element individually the minimum age and the periods that tectonic activity occurred can be assigned. Included with 'tectonic activity' are basin subsidence, (reverse) faulting and uplift. Excluded from this table is doming and piercing from halokinetic activity. E.g. the Cleaver Bank High has been tectonically active during Variscan phases. During the Permian, Triassic and Early and Middle Jurassic no significant tectonic activity occurred. During the Late Kimmerian phase (Late Jurassic) until the Laramide phase, resp. uplift inversion and erosion occurred on the Cleaver Bank High.

\begin{tabular}{|c|c|c|c|c|c|c|}
\hline & Depth maps presented in this paper & & 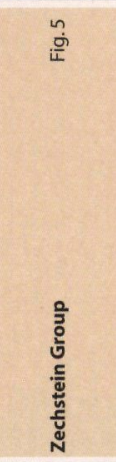 & 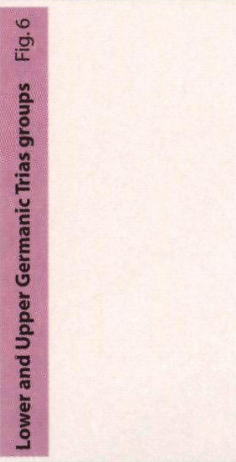 & & 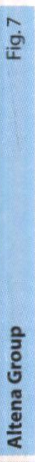 \\
\hline \multicolumn{2}{|r|}{ Orogeny } & \multicolumn{2}{|c|}{ Variscan orogeny } & \multicolumn{2}{|c|}{ Alpine orogeny } & \\
\hline & Tectonic phase and unconformity & Saalian & - & Hardegsen & Early Kimmerian & \\
\hline & $\begin{array}{r}\text { Age of tectonic phase } \\
\text { Regional stress field }\end{array}$ & $\begin{array}{l}290-\mathbf{2 8 0} \mathrm{My} \\
\text { compression }\end{array}$ & extension & $\begin{array}{c}245 \text { - } 247 \text { My } \\
\text { extension }\end{array}$ & $\begin{array}{c}213-204 \text { My } \\
\text { extension }\end{array}$ & \\
\hline & $\begin{array}{r}\text { Tectonic expression } \\
\text { Time }\end{array}$ & $\begin{array}{l}\text { wrench faulting } \\
\text { Late Carboniferous }\end{array}$ & $\begin{array}{l}\text { subsidence } \\
\text { Permian }\end{array}$ & $\begin{array}{l}\text { subsidence } \\
\text { Early Triassic }\end{array}$ & $\begin{array}{l}\text { subsidence } \\
\text { Late Triassic }\end{array}$ & \\
\hline Basins, platforms and highs & Abbreviation & & & & & \\
\hline Ameland Block & $A B$ & & & & & \\
\hline Brabant Massif & BM & & & & & \\
\hline Broad Fourteens Basin & $\mathrm{BFB}$ & & & & & \\
\hline Campine Basin & $\mathrm{CB}$ & & & & & \\
\hline Central Netherlands Basin & CNB & & & & & \\
\hline Central Offshore Platform & COP & & & & & \\
\hline Cleaver Bank High & $\mathrm{CBH}$ & & & 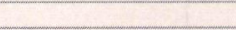 & & \\
\hline Dalfsen High & $\mathrm{DH}$ & & & & & \\
\hline Dutch Central Graben & DCG & & & & & \\
\hline Elbow Spit High & ESH & & & & & \\
\hline Ems Low & EL & & & & & \\
\hline Friesland Platform & FP & & & & & \\
\hline Groningen High & $\mathrm{GH}$ & & & & & \\
\hline Kijkduin High & $\mathrm{KH}$ & & & & & \\
\hline Lauwerszee Trough & LT & & & & & \\
\hline Lower Saxony Basin & LSB & & & & & \\
\hline Maasbommel High & $\mathrm{MH}$ & & & & & \\
\hline Mid North Sea High & MNSH & & & & & \\
\hline Netherlands High & $\mathrm{NH}$ & & & & & \\
\hline Netherlands Swell & NS & & & & & \\
\hline Noord-Holland Platform & NHP & & & & & \\
\hline North Sea Basin & NSB & & & & & \\
\hline Peel Block & PBL & & & & & \\
\hline Rhenish Massif & RM & & & & & \\
\hline Roer Valley Graben & RVG & & & & & \\
\hline Schill Grund High & SGH & & & & & \\
\hline Southern Permian Basin & SPB & & & & 7 & \\
\hline Step Graben & STG & & & & & \\
\hline Terschelling Basin & TB & & & & & \\
\hline Texel-IJsselmeer High & TIJH & & & & & \\
\hline Venlo Block & VBL & & & & & \\
\hline Vlieland Basin & VB & & & & & \\
\hline Vlieland High & $\mathrm{VH}$ & & & & & \\
\hline Voorne Trough & VT & & & & & \\
\hline West Netherlands Basin & WNB & & & & & \\
\hline Winterton High & WH & & & & & \\
\hline Winterton Platform & WP & & & & & \\
\hline Zandvoort Ridge & $\mathrm{ZR}$ & & & & & \\
\hline Zeeland Platform & ZP & & & & & \\
\hline Zuiderzee Low & $\mathrm{ZZL}$ & & & & & \\
\hline Zuid-Limburg Block & ZLB & & & & & \\
\hline \multicolumn{6}{|l|}{ Faults and fault zones } & \\
\hline Feldbiss Fault & $\mathrm{FBF}$ & & & & & \\
\hline Gronau Fault Zone & GFZ & & & & & \\
\hline Hantum Fault Zone & HFZ & & & & & \\
\hline Indefatigable Fault Zone & IDFZ & & & & & \\
\hline Mid-Netherlands Fault Zone & MNFZ & & & & $=$ & \\
\hline Peel Boundary Fault & PBF & & & & & \\
\hline Raalte Boundary Fault & $\mathrm{RBF}$ & & & & & \\
\hline Rifgronden Fault Zone & RGFZ & & & & & \\
\hline Rijen Fault & $\mathrm{RF}$ & & & & & \\
\hline Rotterdam Fault Zone & RDFZ & & & & & \\
\hline Tegelen Fault & TF & & & & & \\
\hline
\end{tabular}


Structural elements of Carboniferous (or older) tectonic age Structural elements of Permian tectonic age Structural elements of Triassic tectonic age

Structural elements of Jurassic tectonic age (incl. Late Cretacous inversion) Structural elements of Cenozoic tectonic age (incl. Early Tertiary inversion)

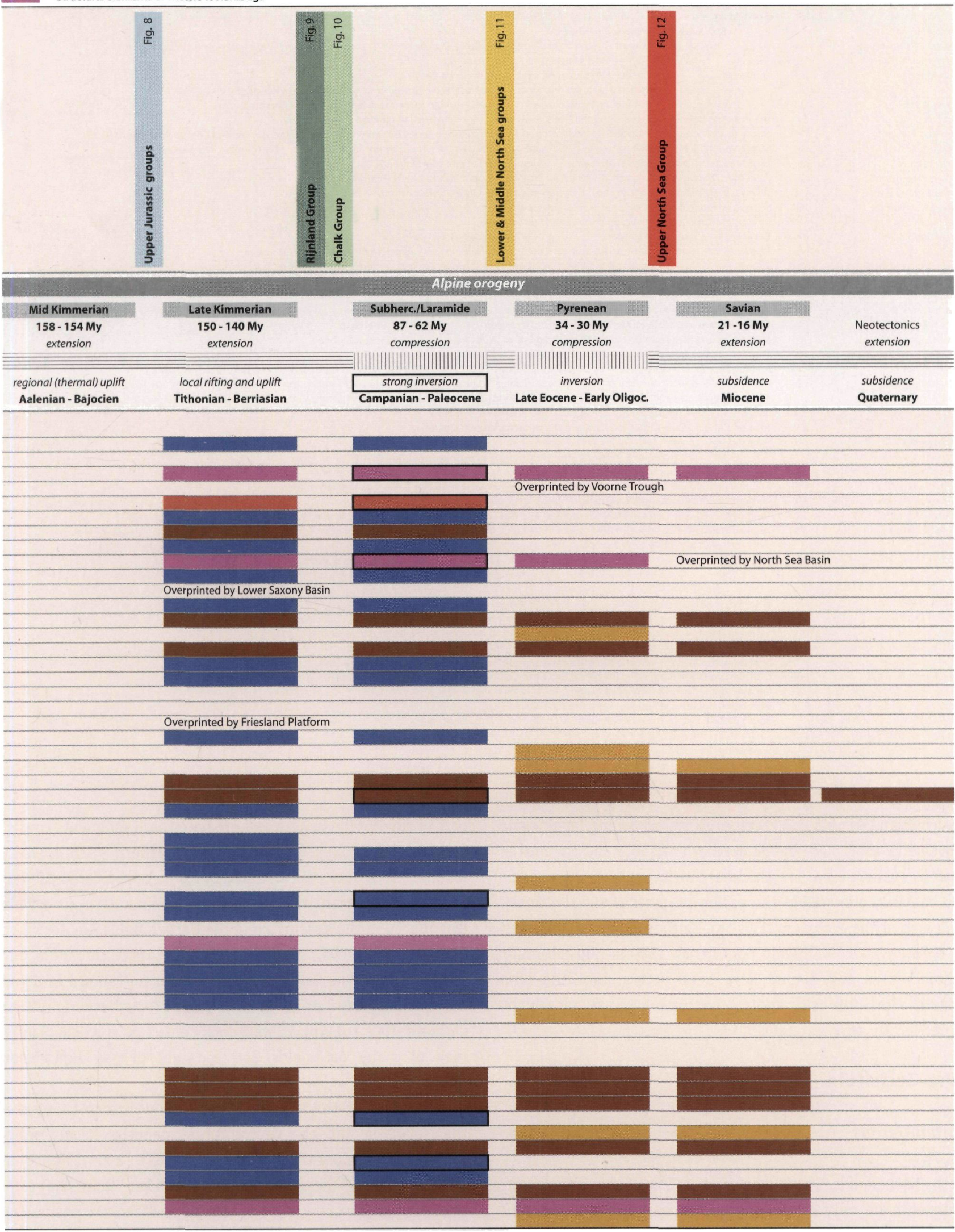


Table 1b. Geological description and abbreviations of regional structural elements.

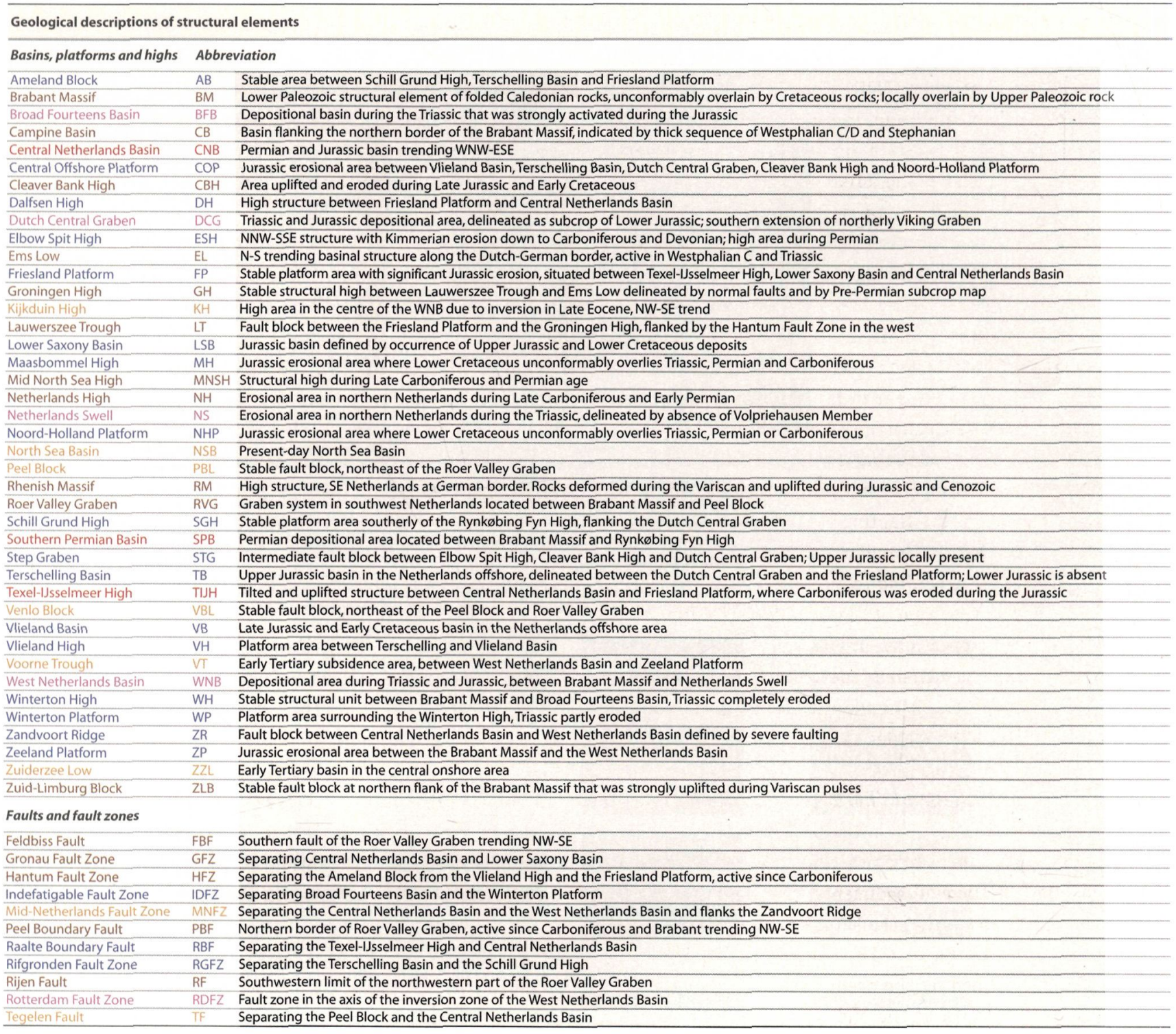

the Permian, Triassic and Cretaceous basins. Strong halokinetic movements took place in the northern offshore and the northeastern onshore area. The thickness variation of Zechstein salt can be easily observed in the geological profiles and the thickness map of the Zechstein (Fig. 5b). Salt structures are revealed by thicknesses of Zechstein larger than $1300 \mathrm{~m}$ (Fig. 5b). Salt pillows, walls and diapirs have been active since the Late Triassic. Both intensity and (re-)activation of salt movement varies locally very strongly.

\section{Pre-Zechstein}

\section{Carboniferous}

In the Netherlands, Early Carboniferous (Tournaisian and Visean) sediments are only known from a few wells. In the southern part of the Dutch onshore and offshore these sediments consist of black limestones whereas in the northern offshore Early Carboniferous rocks are of clastic origin. Upper Carboniferous deposits (Namurian, Westphalian and Stephanian) are widely distributed in the subsurface of the Netherlands (Van Adrichem Boogaert \& Kouwe, 1993 - 1997). The total thickness and distribution of the Carboniferous strata is not known in detail due to their deep burial. In large parts of the Netherlands the Carboniferous subcrop is well-documented as it is the source rock of many gas fields and a target of gas exploration (Mijnlieff, 2005).

The depth of the top of the Carboniferous can be greater than $6000 \mathrm{~m}$ and the Carboniferous deposits locally reach thicknesses of more than $4000 \mathrm{~m}$ (TNO-NITG, 2004). Hence, in many locations these deposits are thicker than the total thickness of the cumulative Permian to Cenozoic deposits. The 
Carboniferous deposits are overlain by Middle and Late Permian sediments of the Upper Rotliegend and Zechstein groups (Fig. 3). The Carboniferous is unconformably overlain by the Early Cretaceous Rijnland Group on structural high elements, such as the Texel-IJsselmeer (TIJH) (Fig. 3c), and Winterton highs (WH) or by the Chalk Group in the southern parts of the Netherlands. Carboniferous strata are absent in the southernmost part of the onshore and offshore and locally on the Elbow Spit High, where Devonian strata directly are overlain by the Late Cretaceous Chalk Group.

The Variscan structural elements map (Fig. 4a) shows the Campine Basin (CB), Roer Valley Graben (RVG), Ems Low (EL) and the Cleaver Bank High ( $\mathrm{CBH})$ that developed in response to Permo-Carboniferous wrench tectonics (Mijnlieff, 2005). Westphalian D strata are present in these synclinal structures which resulted from Variscan tectonics (Schroot \& De Haan, 2003). Most large fault zones that have come into existence during the Permo-Carboniferous have been reactivated repeatedly later, such as the Hantum Fault Zone (HFZ), Gronau Fault Zone (GFZ), Raalte Boundary Fault (RBF) and Peel Boundary Fault (PBF). According to Schroot \& De Haan (2003) the Carboniferous fault system of the Cleaver Bank High shows NW-SE and NE-SW orientations. The orientation of Variscan faults in NW-Europe is generally developed in a NW-SE to WNW-ESE direction (Scheck-Wenderoth \& Lamarche, 2004; Schroot \& De Haan, 2003; Ziegler et al., 2004).

\section{Lower and Upper Rotliegend (Early and Middle Permian)}

After the transpressional tectonics of the Variscan orogeny, Lower and Upper Rotliegend sediments were deposited under continental conditions during the Early and Middle Permian in the Southern Permian Basin (SPB) (Fig. 4b). The Southern Permian Basin is defined by the occurrence of Rotliegend and Zechstein deposits, south of the Mid North Sea High (MNSH) and the Ringkøbing Fyn High. The thickness of the Rotliegend section reaches a maximum value of more than $900 \mathrm{~m}$ in the G-block in the northeastern offshore area (Fig. 4b; Geluk, 2005). Subsidence of the central parts of the Southern Permian Basin took place during the Middle and Late Permian, in conjunction with the pre-cursor of the Broad Fourteens Basin (BFB) and the Central Netherlands Basin (CNB). The Southern Permian Basin has developed in a WNW-ESE direction north of the Brabant Massif (BM). The local absence of the Rotliegend deposits within the Southern Permian Basin, such as on the Texel-IJsselmeer High (TIJH) and on the Winterton High (WH), is the result of Jurassic erosion. However, it was also shown by Rijkers \& Geluk (1993) that the Texel-IJsselmeer High was a high structure during the Permian, which is indicated by the thickness development and sedimentary facies changes of the Upper Rotliegend and Zechstein groups around the high.

\section{Zechstein Group (Late Permian)}

\section{Depth, thickness and basin development}

The outlines of the Zechstein basin coincide largely with the occurrence of deposits of the Upper Rotliegend Group (Fig. 3b). The southernmost occurrence of Zechstein sediments defines the southern margin of the Southern Permian Basin. The present-day depth of the base of the Zechstein Group ranges from almost $700 \mathrm{~m}$ in the southeastern part of the Netherlands to more than $5000 \mathrm{~m}$ in the Dutch Central Graben, the Broad Fourteens Basin and the West Netherlands Basin (Fig. 5a). Basins that have subsided further during the Early and Late Kimmerian phases, such as the Dutch Central Graben (DCG), Terschelling Basin (TB), Broad Fourteens Basin (BFB), Ems Low (EL) and Roer Valley Graben (RVG), are clearly outlined in the depth map of the base of the Zechstein Group (Fig. 5a). The thickness of the Zechstein Group increases strongly to the north up to more than $900 \mathrm{~m}$ on Late Jurassic platforms (Fig. 5b).

\section{Structural development}

At the Maasbommel (MH), Winterton (WH), Texel-IJsselmeer (TIJH), Dalfsen (DH) and Elbow Spit highs (ESH) the Zechstein is absent due to Mid- and Late Kimmerian erosion (Figs $5 \mathrm{a}$ and 5b). The absence of Zechstein deposits on the Texel-IJsselmeer High is the result of strong Mid- and Late Kimmerian uplift and erosion (Rijkers \& Geluk, 1994). In the southern part of the Netherlands only thin Zechstein deposits are present due to shallow basin development.

The Dutch Central Graben and the Terschelling Basin show pronounced occurrences of salt diapirs and walls. The northeastern onshore and northern offshore areas are characterized by the widespread occurrence of salt structures with local thicknesses of more than $1300 \mathrm{~m}$ (Fig. 5b). The area of mobilized Zechstein salt is clearly visible by the lateral thickness variations. In the areas that have been tectonically active, such as the Terschelling Basin and the Dutch Central Graben, the original Zechstein depositional thickness is obscured by halokinesis (Fig. 5b). On platforms like the Cleaver Bank High and the Ameland Block, where post-Zechstein tectonics have been relatively quiet, the Zechstein is thicker than $900 \mathrm{~m}$, which indicates the minimum depositional thickness of the Zechstein sequence for the offshore E, F, K, L and M-blocks. The absence of Zechstein deposits on Kimmerian highs in the northern salt province is the result of strong Kimmerian uplift and erosion. In the Dutch Central Graben (DCG), Terschelling Basin (TB) and the western part of the Schill Grund High (SGH) the Zechstein salt is locally absent due to salt movement (Fig. 5b). The thin Zechstein sections in these halokinetic areas consist of residual carbonates and anhydrites. 


\section{Lower and Upper Germanic Trias groups}

\section{Depth, thickness and basin development}

The present-day depth of the base of the Lower Germanic Trias Group ranges from approximately $500 \mathrm{~m}$ in eastern Netherlands to over $5000 \mathrm{~m}$ in the Dutch Central Graben (Fig. 6a). As the result of Jurassic subsidence, thick Triassic deposits have only been preserved in the Dutch Central Graben, Terschelling, Broad Fourteens, Central Netherlands, Lower Saxony basins and Roer Valley Graben (Figs $6 \mathrm{a}$ and $6 \mathrm{~b}$ ). In the other areas the Triassic deposits were eroded during the Late Jurassic. The total thickness of Triassic deposits amounts to more than 1800 $m$ in the Dutch Central Graben (Fig. 6b). During the Triassic the Dutch Central Graben, Roer Valley Graben and the Broad Fourteens Basin have subsided relatively faster than the surrounding highs which resulted in greater thicknesses in these basins (Fig. 6b; Geluk, 2005). The Netherlands Swell is the area in the northern part of the Netherlands that is strictly defined by the subcrop of the Volpriehausen Sandstone Member in the Lower Germanic Trias Group (Geluk, et al., 2005). The Netherlands Swell was a relative high during the Early Triassic and was paralleled by the Hardegsen event in the Early Triassic (Geluk, 2005; Fig. 4c).

\section{Structural development}

Erosion of Triassic deposits occurred on structural highs such as the Elbow Spit (ESH), Cleaver Bank (CBH), Texel-IJsselmeer (TIJH), Dalfsen (DH), Winterton (WH) and Maasbommel highs (MH) and Friesland Platform (FP), sometimes removing the entire Triassic succession (Figs $6 \mathrm{a}$ and $6 \mathrm{~b}$ ). The greater part of the erosion of Triassic deposits occurred in response to Late Jurassic uplift. Moreover, salt walls and erosion obscure such faulting. The borders of the Dutch Central Graben and the Terschelling Basin appear to be preferential sites for the development of thrust (inversion) faults together with salt walls and diapirs. The faults in the Triassic maps in Figs $6 a$ and $6 \mathrm{~b}$ are the cumulative result of Jurassic rifting and Late Cretaceous inversion tectonics. Triassic extensional tectonics in the Netherlands was paralleled by rifting in the ArcticNorth Atlantic domain (Ziegler, 1988).

\section{Altena Group (Early and Middle Jurassic)}

\section{Depth, thickness and basin development}

The depth of the base of the Altena Group ranges from less than $1000 \mathrm{~m}$ in the eastern Netherlands to more than $5000 \mathrm{~m}$ in the Dutch Central Graben and the Broad Fourteens Basin (Fig. 7a). In the easternmost part of the Central Netherlands Basin, strata of the Altena Group outcrop. The Central Netherlands Basin has developed in a WNW-ESE direction and the Dutch
Central Graben in a N-S direction (Fig. 4d). The Broad Fourteens Basin, Roer Valley Graben and West Netherlands Basin have developed in NW-SE to NNW-SSE directions (Fig. 4d). The Hantum Fault Zone, as the southern boundary of the Terschelling Basin, is considered to be the feature link between the Lower Saxony Basin and the southern parts of the Dutch Central Graben. In addition, the Vlieland Basin (VB) has been activated in response to a Late Jurassic dextral strike-slip faulting (Herngreen et al., 1991).

\section{Structural development}

Due to Late Cretaceous basin inversion and uplift, Lower Jurassic deposits have been partly eroded in the Central Netherlands Basin, especially on higher fault blocks (Figs 7a and 7b; Fig. 3). The Central Netherlands Basin and the Roer Valley Graben have been strongly inverted during the Subhercynian/Laramide phase removing most of its Jurassic (and Cretaceous) infill (Figs 7a, 9a and 10a). Local uplift and subsequent erosion during Middle Jurassic to Early Cretaceous tectonic phases have almost completely removed Altena deposits on the structural highs and platform areas (Fig. 7a). In the transition zone between the West Netherlands Basin and the Roer Valley Graben, subtle but distinct structural NNW-SSE and WNW-ESE fault directions can be observed on the depth and thickness maps of the Altena Group (Figs 7a and 7b).

\section{Schieland, Scruff and Niedersachsen groups (Late Jurassic)}

\section{Depth, thickness and basin development}

Upper Jurassic deposits are only found in depocentres of the Dutch Central Graben (DCG), Roer Valley Graben (RVG), Vlieland (VB), Terschelling (TB), Broad Fourteens (BFB), West Netherlands (WNB) and Central Netherlands basins (CNB) (Figs 8a and 8b). The geographical extension of Late Jurassic deposits is very similar to those of the Early Jurassic deposits (Fig. 7a). The depth of the Upper Jurassic sediments ranges from almost 100 $\mathrm{m}$ in the eastern Netherlands to over $3000 \mathrm{~m}$ in the Dutch Central Graben, Terschelling Basin, Vlieland Basin and Broad Fourteens Basin (Fig. 8a). The thickness of the Upper Jurassic deposits is strongly influenced by inversion and erosion during the Late Cretaceous. A thickness of over $1000 \mathrm{~m}$ is only present in the most active Late Jurassic structures, such as the Dutch Central Graben and the Broad Fourteens Basin (Fig. 8b). These basins were deformed by strong local rift tectonics of the Late Kimmerian phases. Complex Late Jurassic tectonics obscure the earlier geological deformation history because Late Kimmerian tectonics initiated both basin subsidence and uplift of platforms and highs. Upper Jurassic deposition started in the Dutch Central Graben during the 0xfordian in continental and lacustrine facies. These depositional environments of the 
Kimmeridgian in the Dutch Central Graben expanded towards the south into the Broad Fourteens and the West Netherlands basins during the Portlandian (Van Adrichem Boogaert \& Kouwe, 1993 - 1997; Herngreen \& Wong, 1989).

\section{Structural development}

On the Late Jurassic structural highs the deposits of the Triassic, Zechstein and Rotliegend are completely eroded (Fig 4d). Late Jurassic platforms are delineated by complete erosion of Altena and/or Upper Jurassic deposits. Late Jurassic basins in the southern offshore and onshore of the Netherlands are controlled by NW-SE trending fault systems, with WNW-ESE and NNW-SSE trending faults playing a subsidiary role (Fig. 8a). Periods of enhanced salt flow correspond with tectonic phases (Remmelts, 1996). Late Jurassic faulting together with sea level fluctuations resulted in a large variety of facies systems ranging from open marine to continental deposits (Herngreen \& Wong, 1989; Van Adrichem Boogaert \& Kouwe, 1993 - 1997). The Zuidwal volcanic complex in the Vlieland Basin was active during the Late Jurassic, dividing this basin into a continental and a marine part (Figs $8 \mathrm{a}$ and $8 \mathrm{~b}$ ). Volcanic activity in the Vlieland Basin was coupled to transpressional wrench tectonics during the 0xfordian (Herngreen et al., 1991). Late Jurassic rifting and wrench tectonics in the Netherlands was paralleled by a major extensional event in the central and northern North Sea as well by the Arctic-North Atlantic rifting phase (Ziegler, 1988, 1990), locally referred to as Late Kimmerian rifting phase.

\section{Rijnland Group (Early Cretaceous)}

\section{Depth, thickness and basin development}

The present-day depth of the Rijnland Group ranges from the outcrops in the eastern part of the Netherlands to more than $3000 \mathrm{~m}$ in the West Netherlands Basin, the Central Offshore Platform (COP), the Schill Grund High (SGH) and the northern offshore (Fig. 9a). The thickness map of the Rijnland Group shows the Lower Cretaceous depocentres in the Broad Fourteens and the West Netherlands basins. The Vlieland, Terschelling and Lower Saxony basins formed minor depocentres (Fig. 9b). The present-day depth and occurrence of deposits of the Rijnland Group is strongly influenced by Late Cretaceous inversion (Fig. 9a). Erosion of Rijnland deposits occurred in the Roer Valley Graben, Central Netherlands Basin and Dutch Central Graben (Fig. 9a). The present-day depth of the Rijnland Group of more than $3000 \mathrm{~m}$ in the A- and B-blocks is partly due to the large basin subsidence of the North Sea Basin during the Cenozoic (Fig. 9a).

\section{Structural development}

As a result of Late Cretaceous inversion, the Rijnland Group is locally absent or reduced in thickness in the areas of strongest inversion, especially in the West Netherlands Basin (Fig. 9a). From the depth maps it can be concluded that inversion has also occurred in the Roer Valley Graben, Central Netherlands Basin and Broad Fourteens Basin (Figs 9a and 9b). The thickness map of the Rijnland Group also reveals intense salt tectonics on the Central Offshore Platform and in the Terschelling Basin and the southern part of the Dutch Central Graben, where the Rijnland Group is locally thin or absent.

\section{Chalk Group (Late Cretaceous)}

\section{Depth and thickness}

The Chalk Group comprises sediments of Cenomanian to Danian age (Van Adrichem Boogaert \& Kouwe, 1993 - 1997). The base of the Chalk Group outcrops in the eastern and southern parts of the Netherlands (Figs 10a and 10b). The depth increases towards the north to more than $2800 \mathrm{~m}$ in the northern offshore blocks. The base of the Chalk Group is uplifted to $1500 \mathrm{~m}$ in the inverted Dutch Central Graben (Fig. 10a). More than $1800 \mathrm{~m}$ of sediments of the Chalk Group have been preserved on the Jurassic platforms, whereas Late Cretaceous inversion has partly and completely removed the sediments across the axial parts of the West Netherlands (WNB), Broad Fourteens (BFB), Central Netherlands (CNB), Vlieland (VB) and Lower Saxony basins (LSB) and Dutch Central Graben (DCG) (Figs $4 \mathrm{e}$ and 10b). Thin deposits of Danian age, that are stratigraphically the top of the Chalk Group, have been deposited in the inverted basins after the Subhercynian phase. These occurrences are absent on the presented maps (Figs 10a and $10 \mathrm{~b})$ due to their small thickness.

\section{Structural development}

The axes of maximum inversion are deduced from the regional distribution and thickness of the Upper Cretaceous (Fig. 4e). The tectonic inversion phases seem to have been active simultaneous in most basins. Inversion of these basins appears to have been synchronous during the Subhercynian (SantonianCampanian), Laramide (Paleocene) and Pyrenean (Eocene) phases of intraplate compression that is attributed to collisional coupling of the Alpine orogenic wedge with its northern foreland (Heybroek, 1974; Ziegler, 1990; De Jager, 2003; Heybroek, 1974; Ziegler, 1990; Van der Molen, 2004). The strongest inversion occurred in the Central Netherlands Basin where the Raalte Boundary Fault has a reversed offset of more than $2000 \mathrm{~m}$ (Fig. 3b: E-E'). 


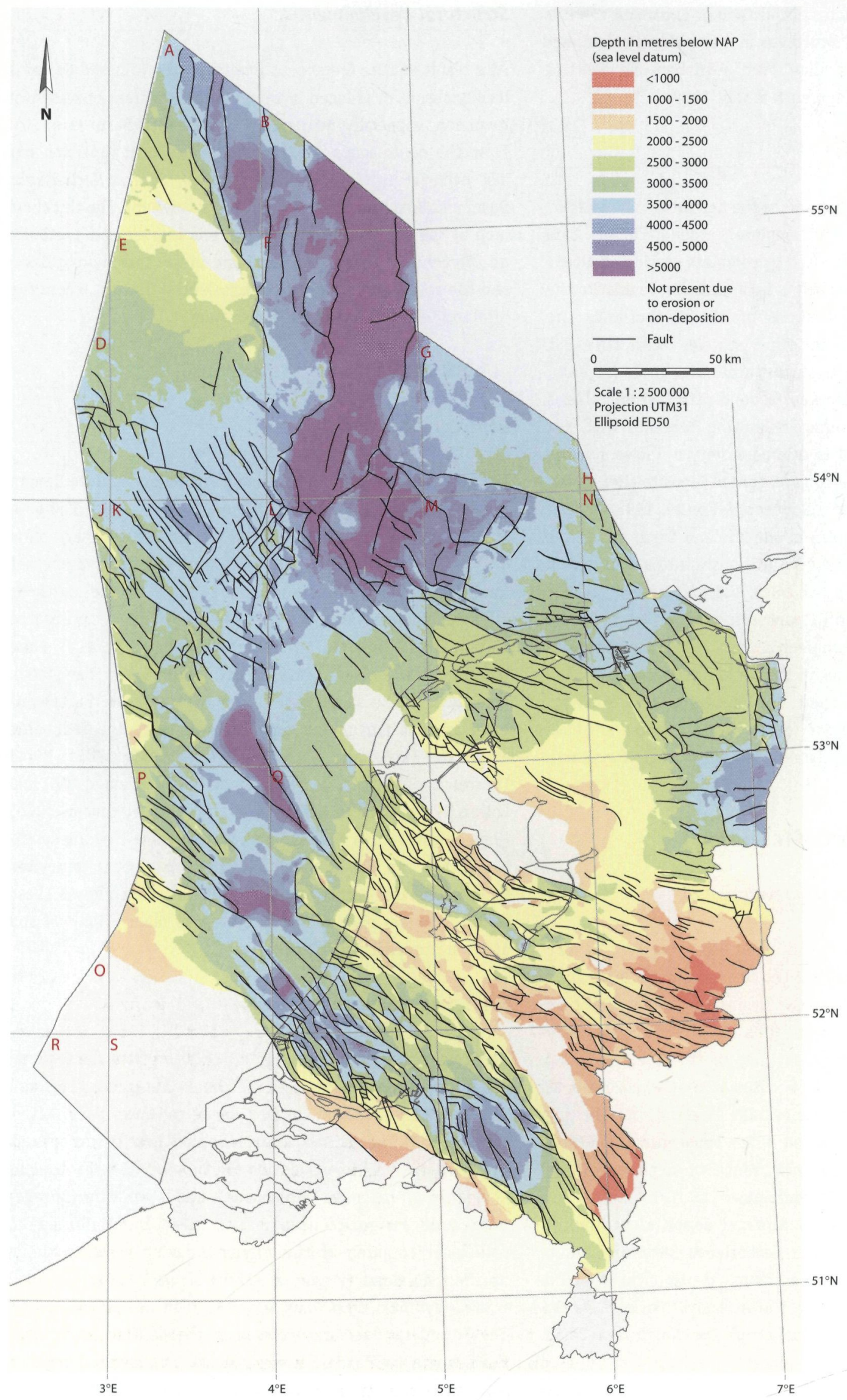

Fig. 5a. Depth map of the base of the Zechstein Group (Late Permian). 


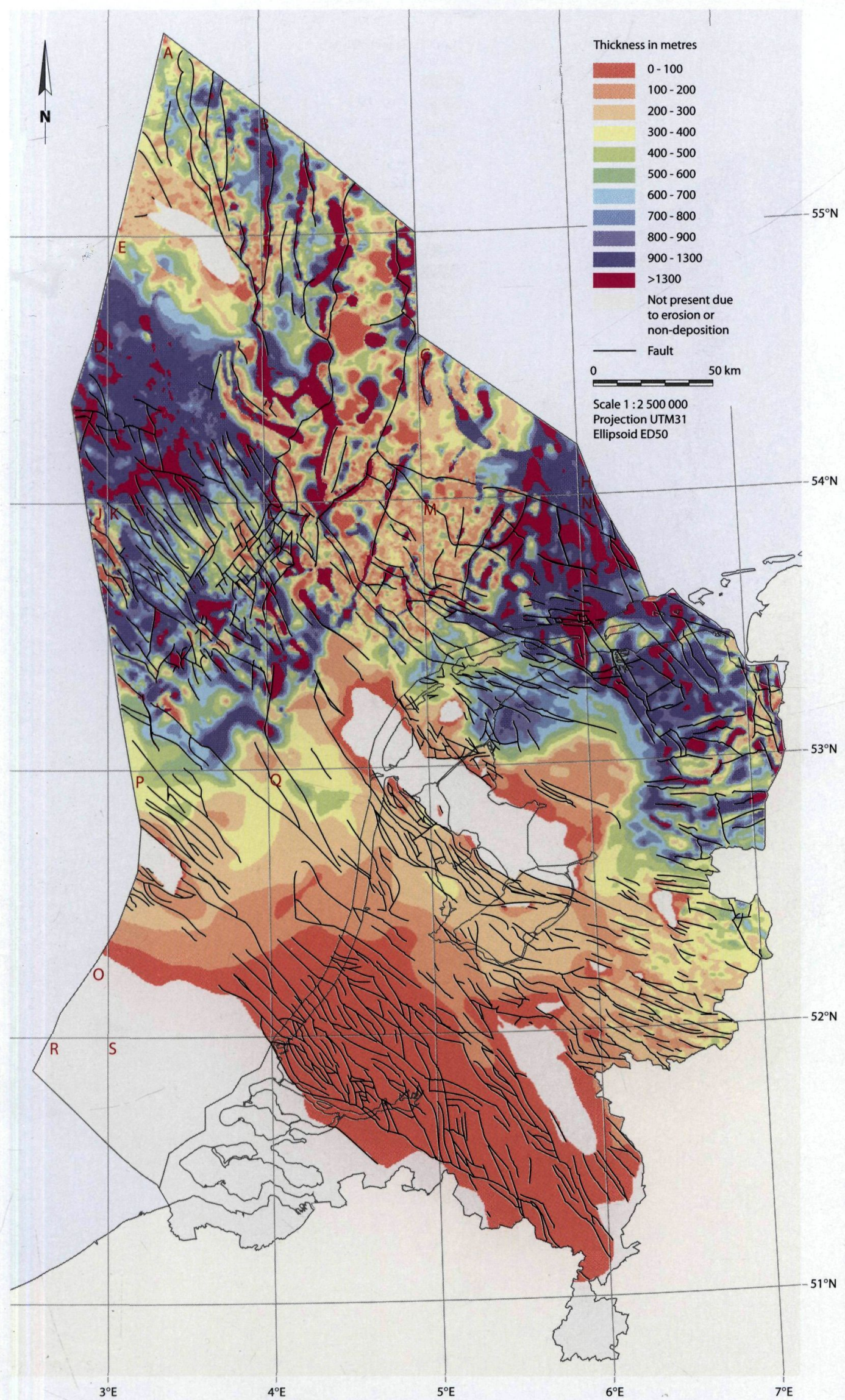

Fig. 5b. Thickness map of the Zechstein Group (Late Permian). 


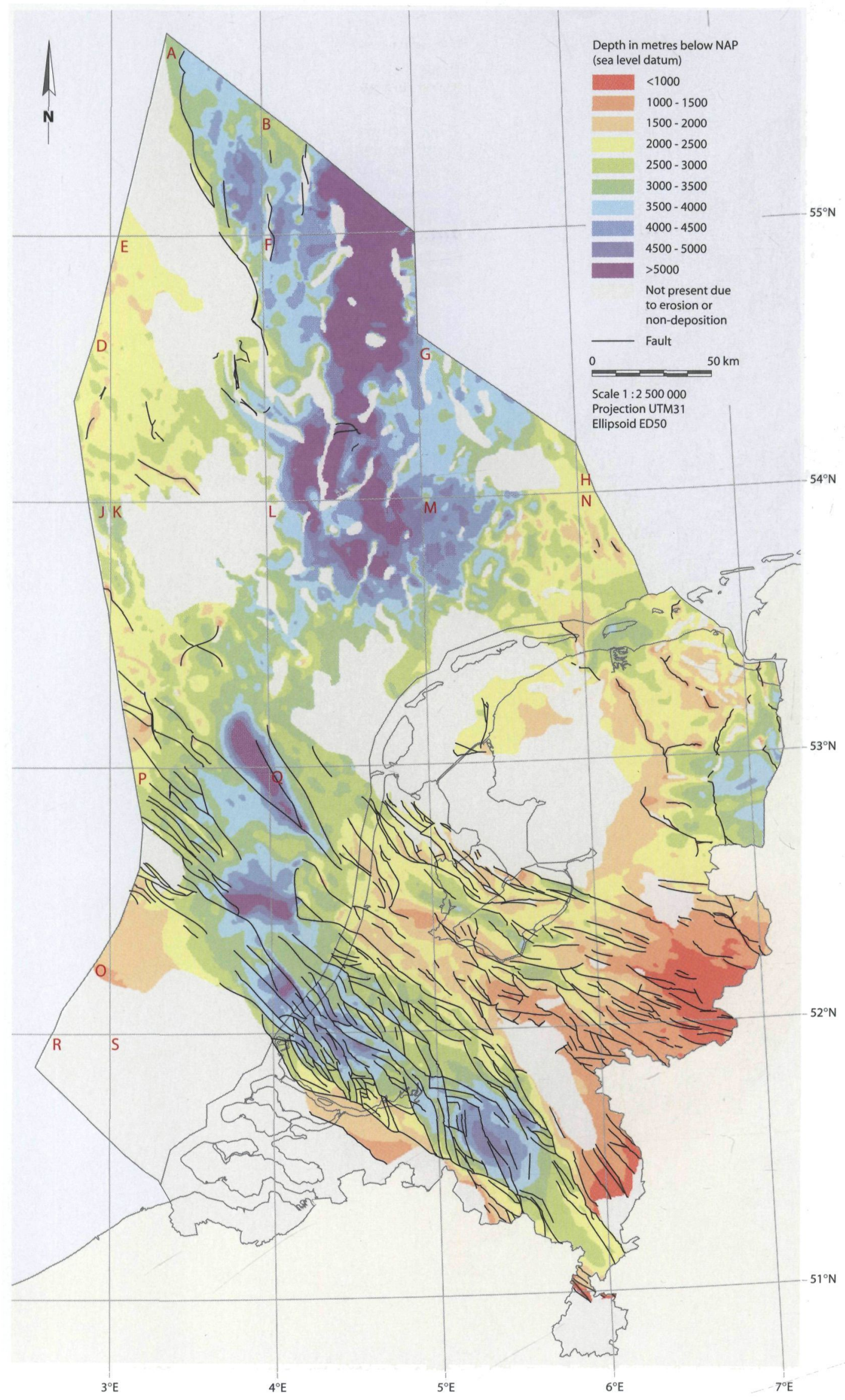

Fig. 6a. Depth map of the base of the Lower Germanic Trias Group. 


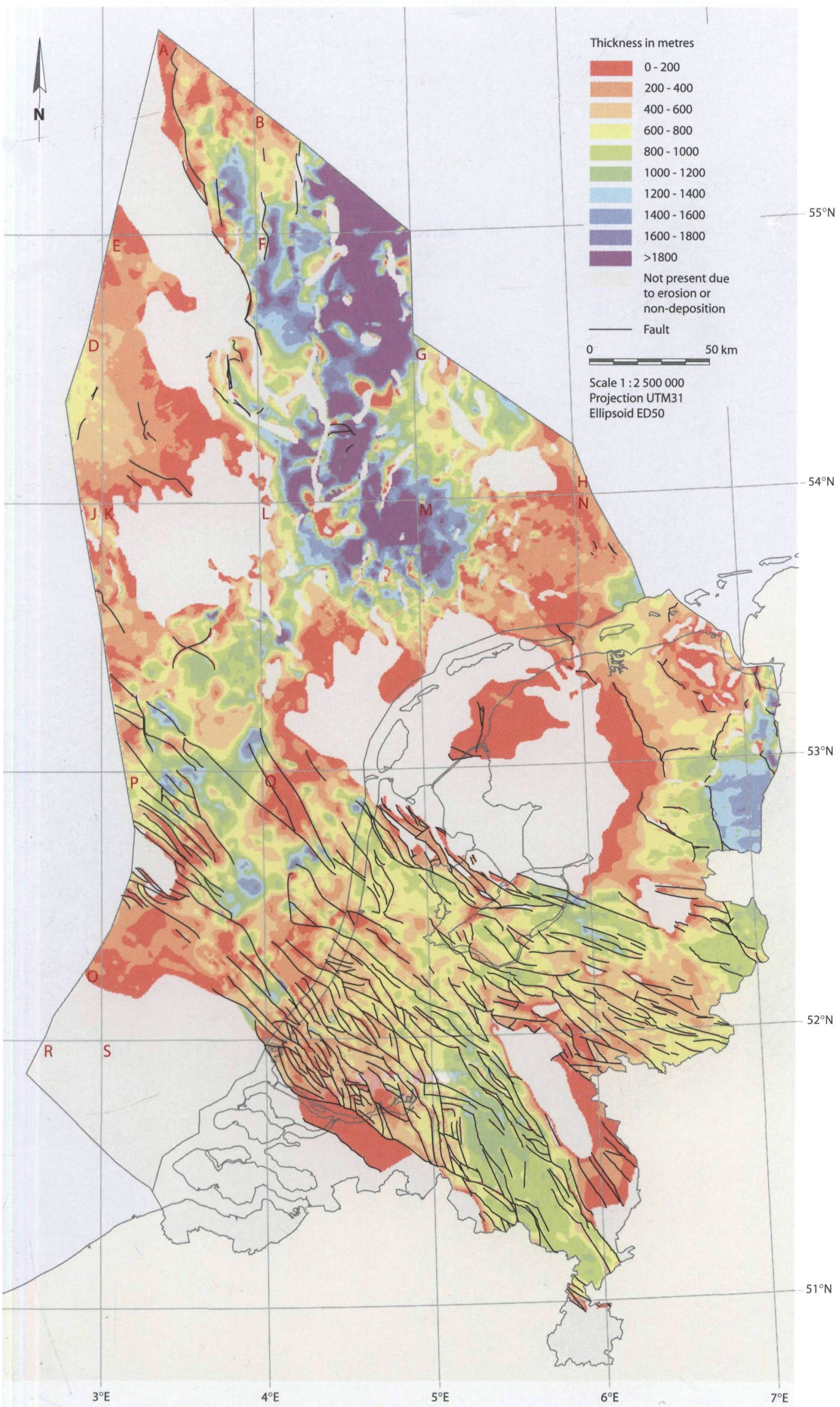

Fig. 6b. Thickness map of the combined Lower and Upper Germanic Trias groups. 


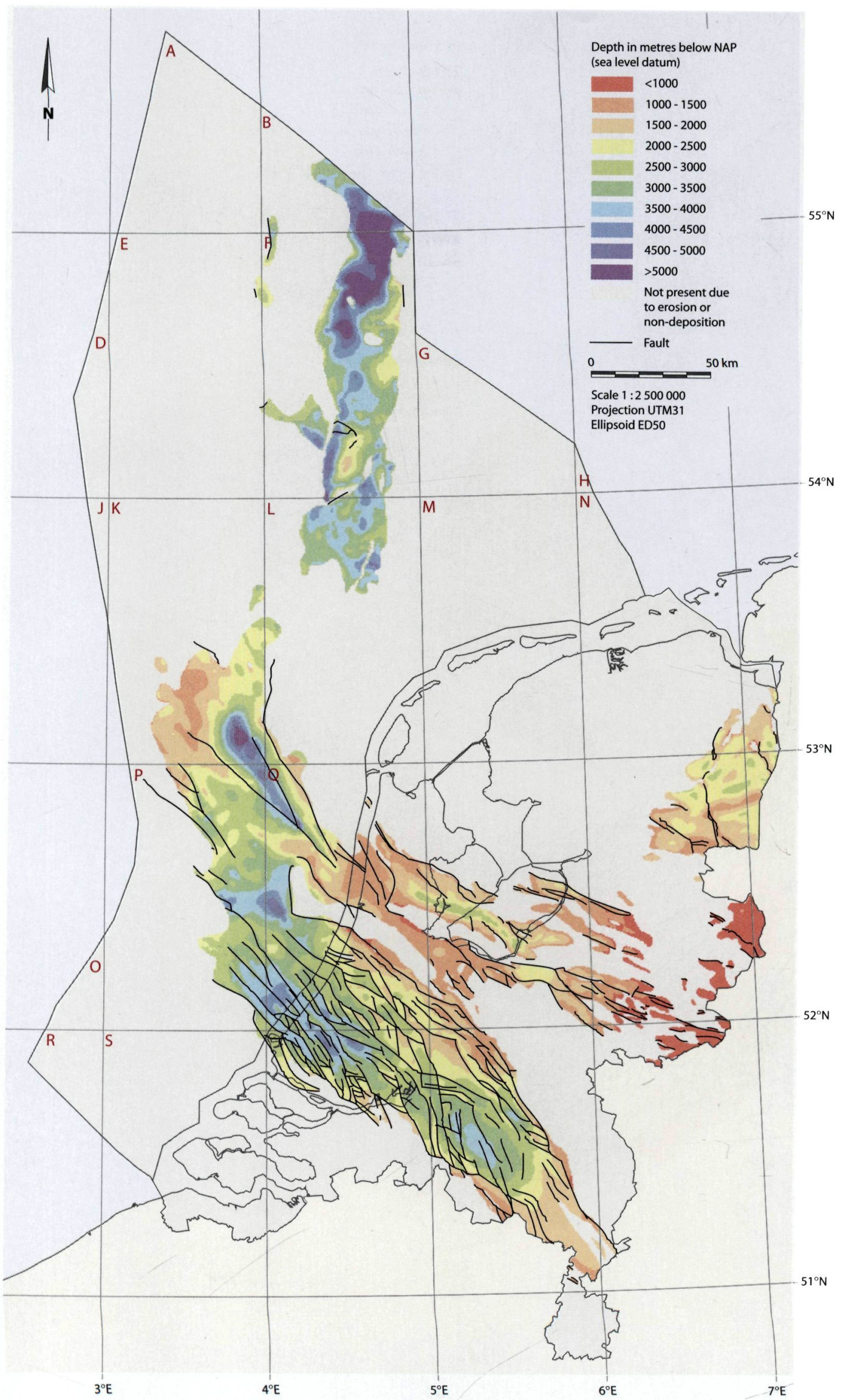

Fig. 7a. Depth map of the base of the Altena Group (Early and Middle Jurassic). 


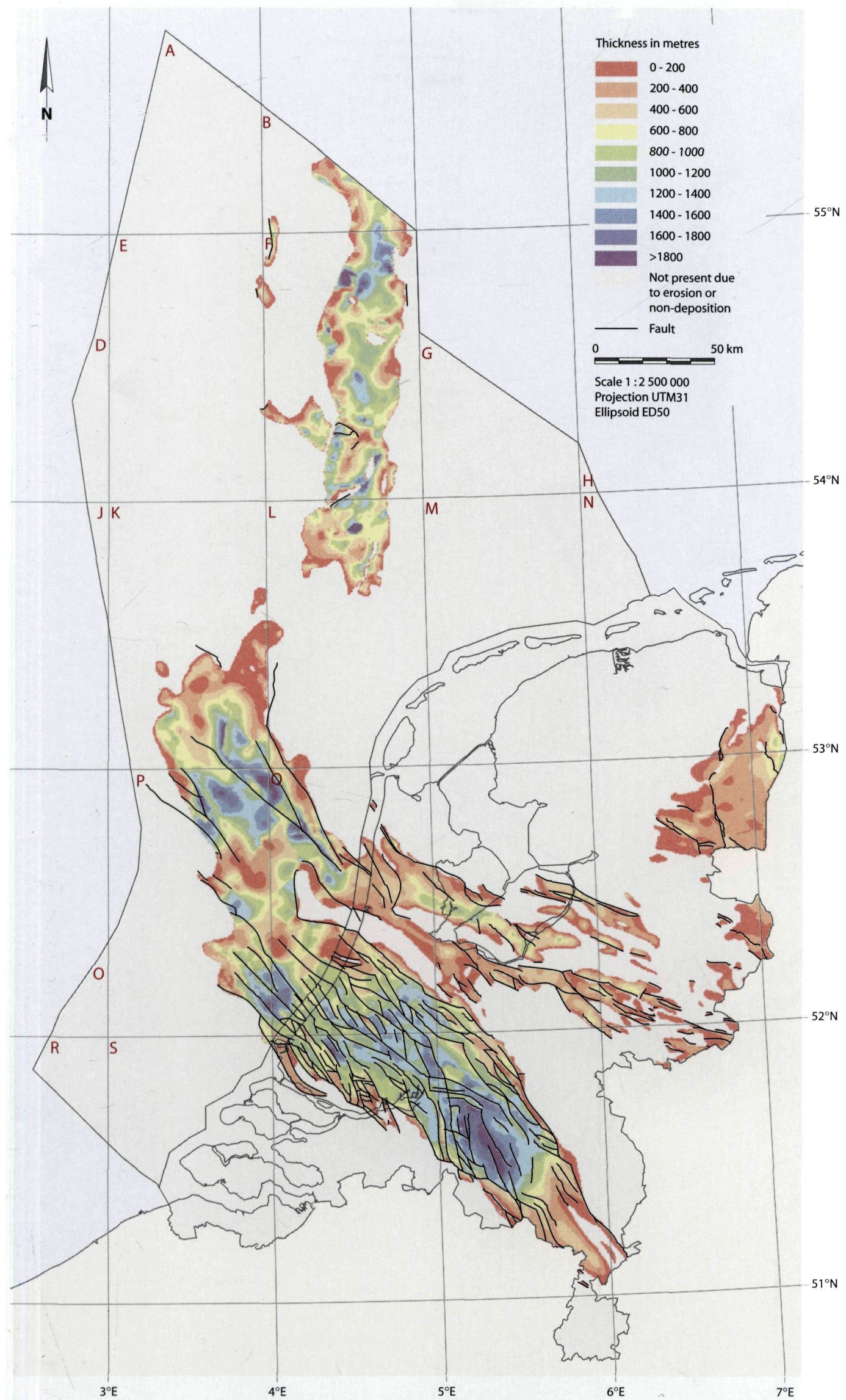

Fig. 7b. Thickness map of the Altena Group (Early and Middle Jurassic). 


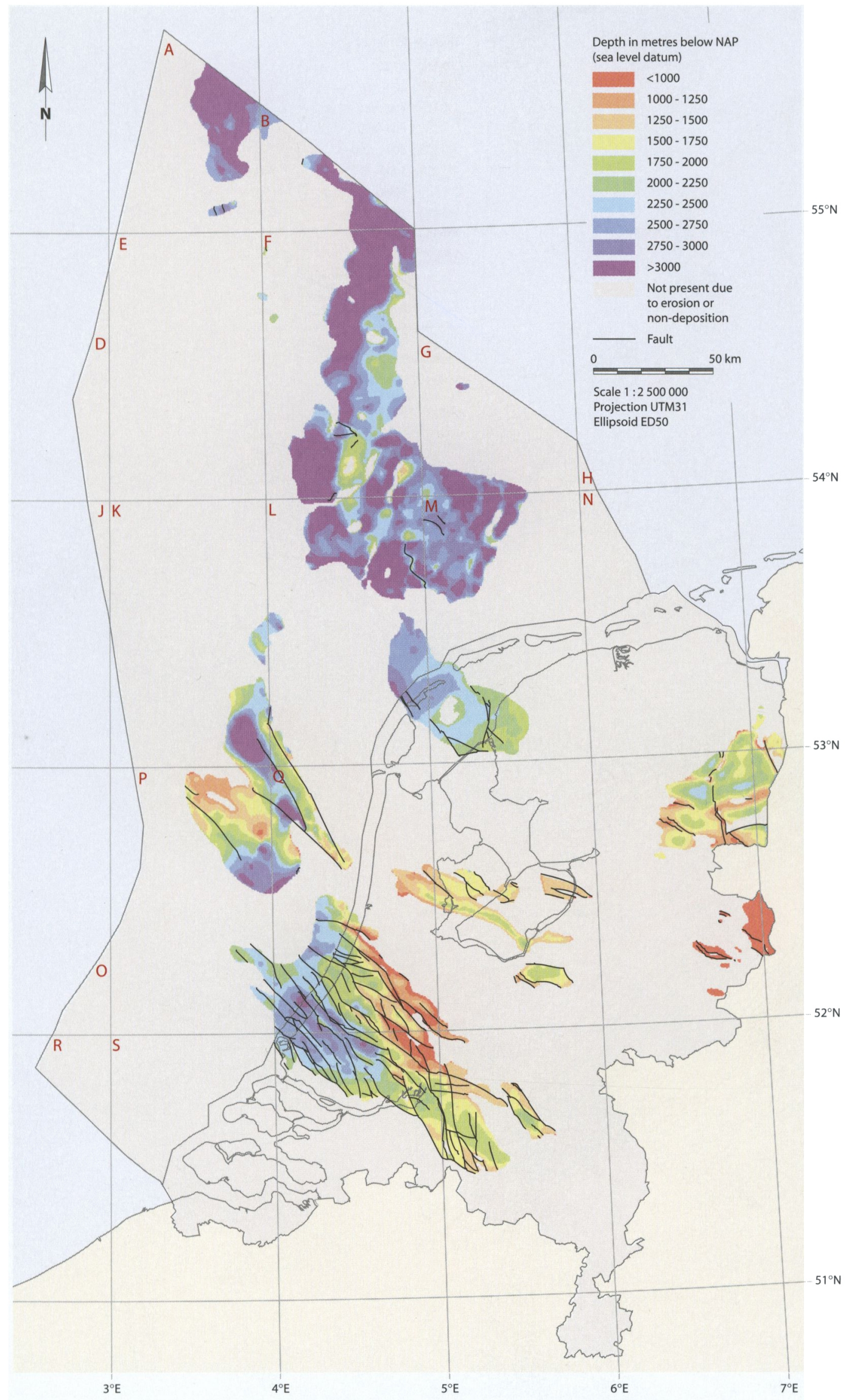

Fig. 8a. Depth map of the base of the Schieland, Scruff and Niedersachsen groups (Late Jurassic). 


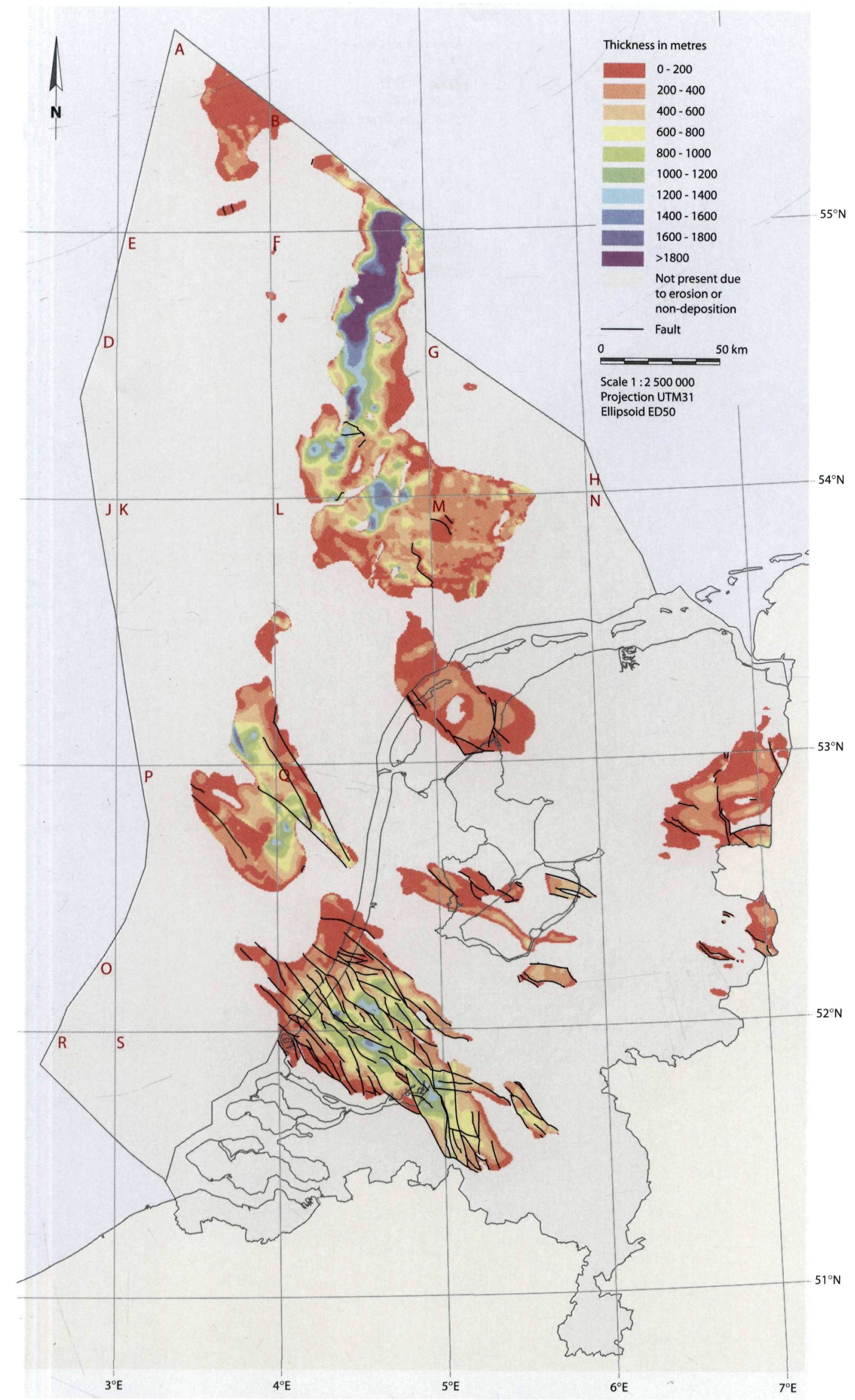

Fig. 8b. Thickness map of the Schieland, Scruff and Niedersachsen groups (Late Jurassic). 


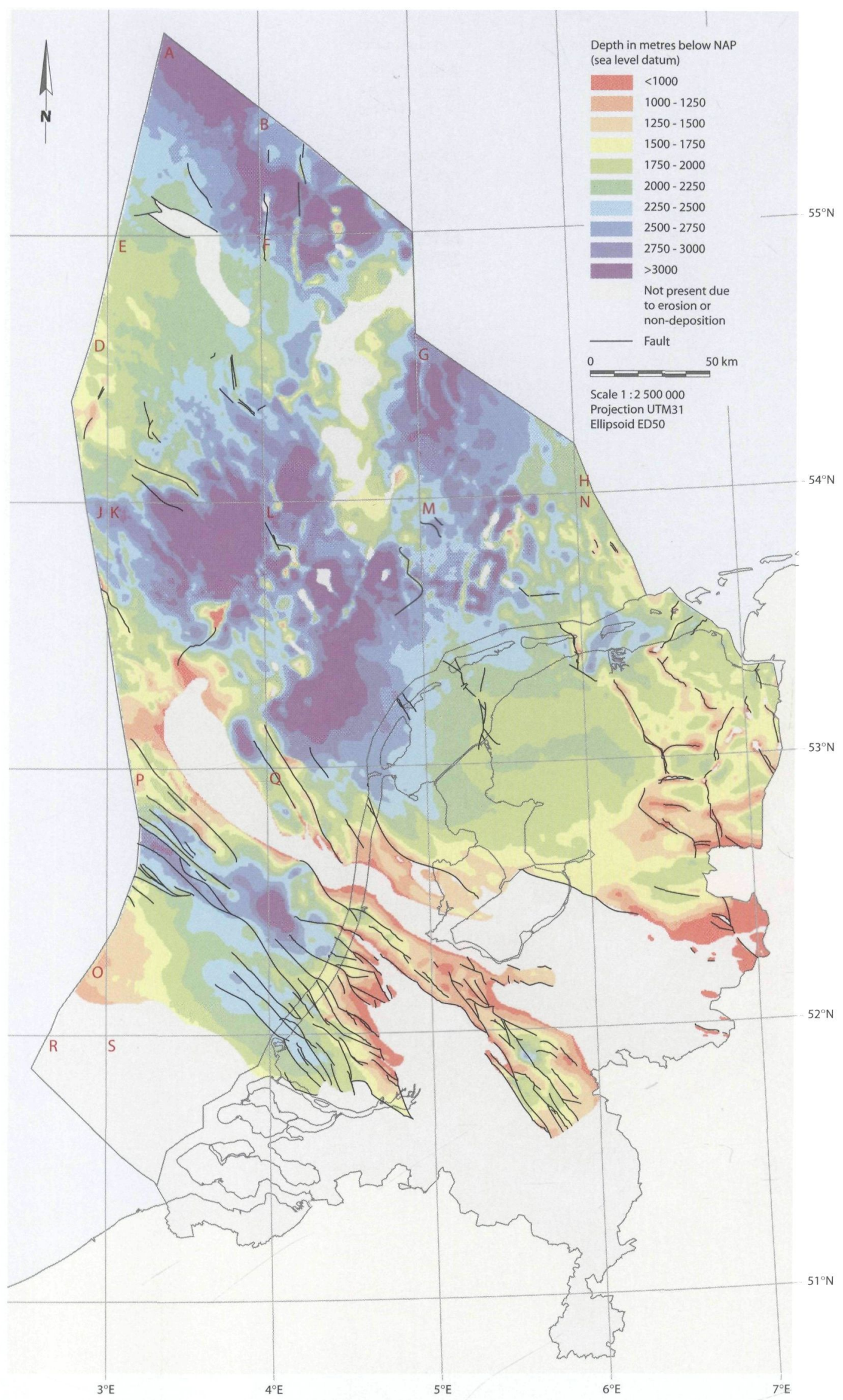

Fig. 9a. Depth map of the base of the Rijnland Group (Early Cretaceous). 


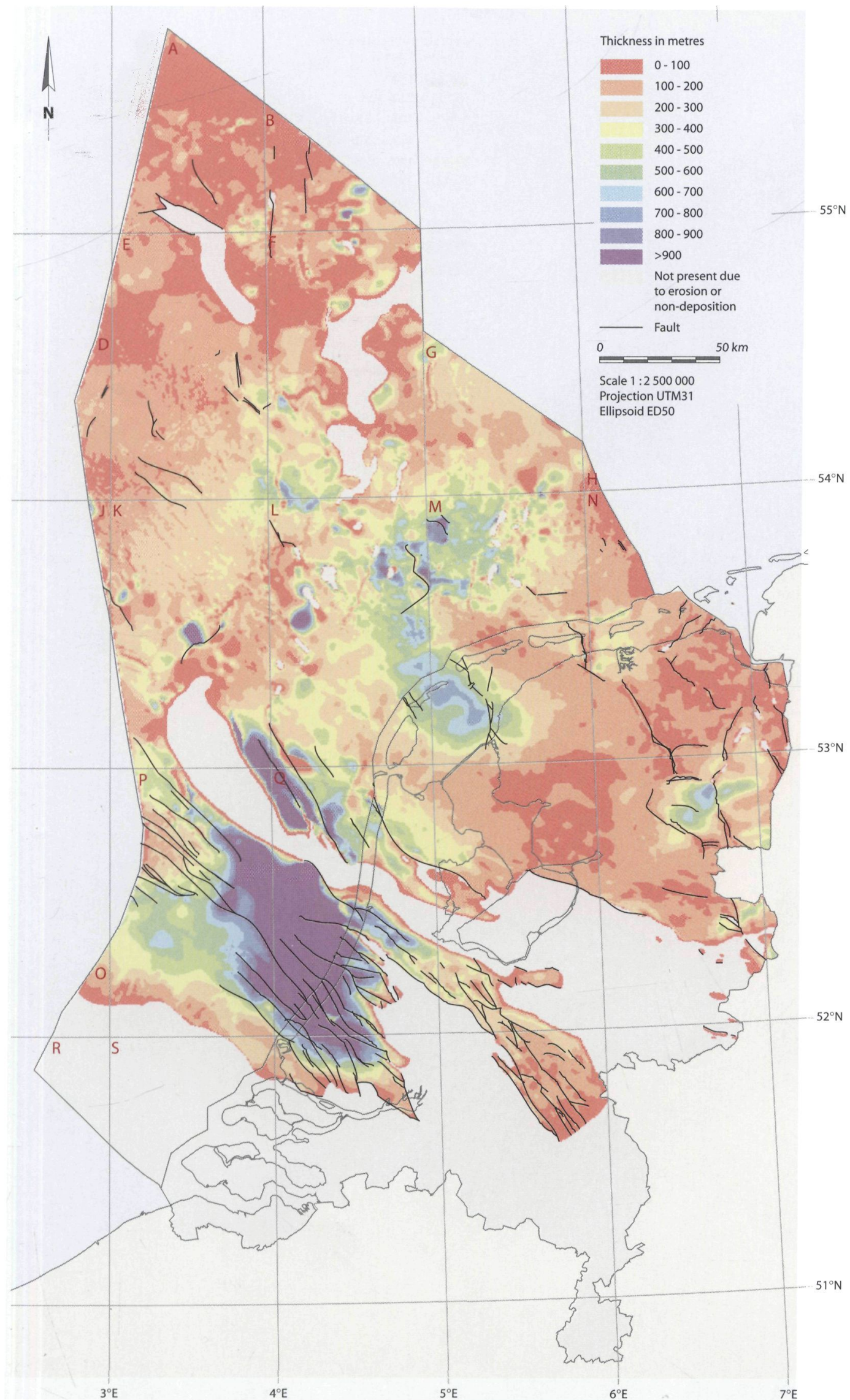

Fig. 9b. Thickness map of the Rijnland Group (Early Cretaceous). 


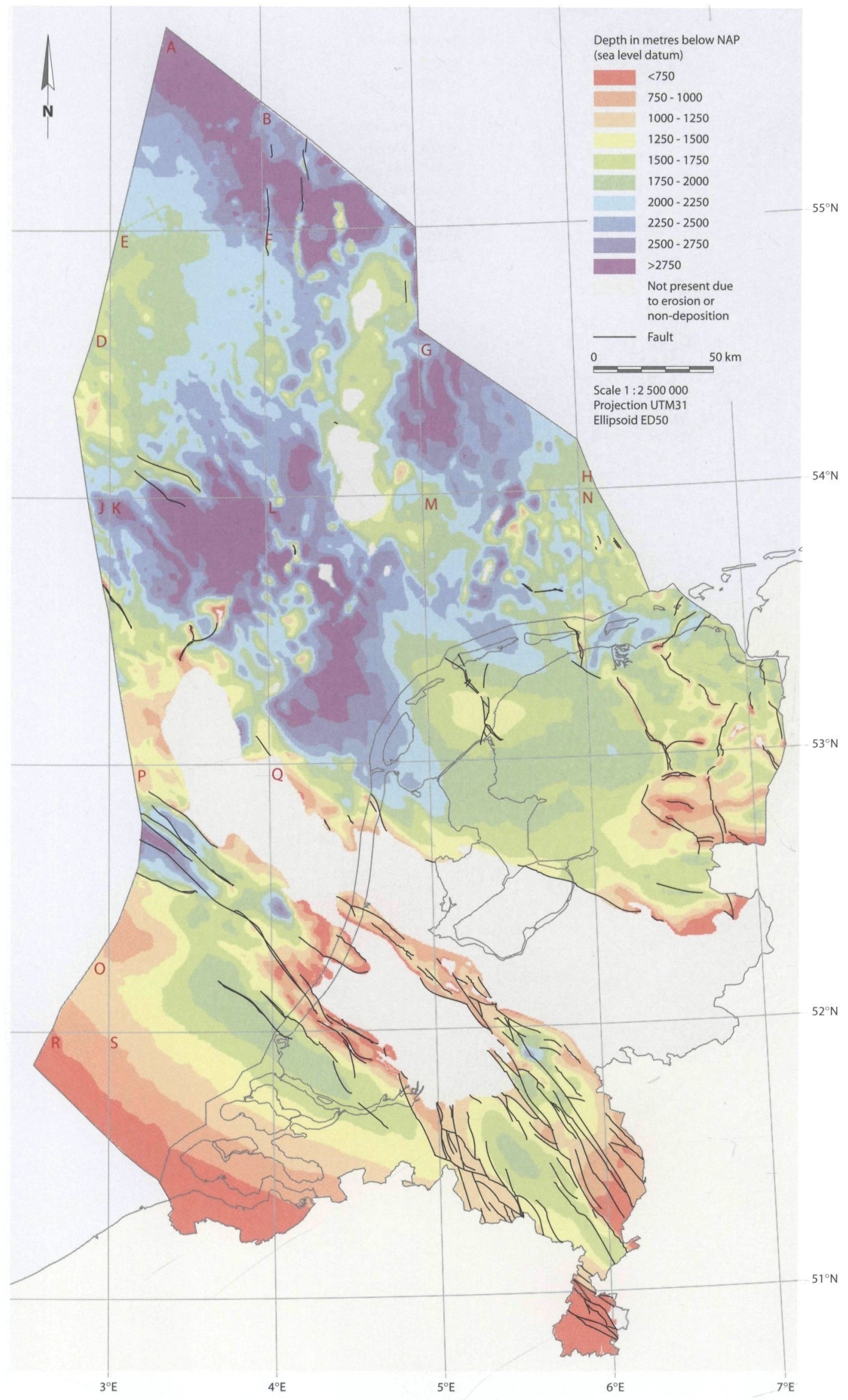

Fig. 10a. Depth map of the base of the Chalk Group (Late Cretaceous). 


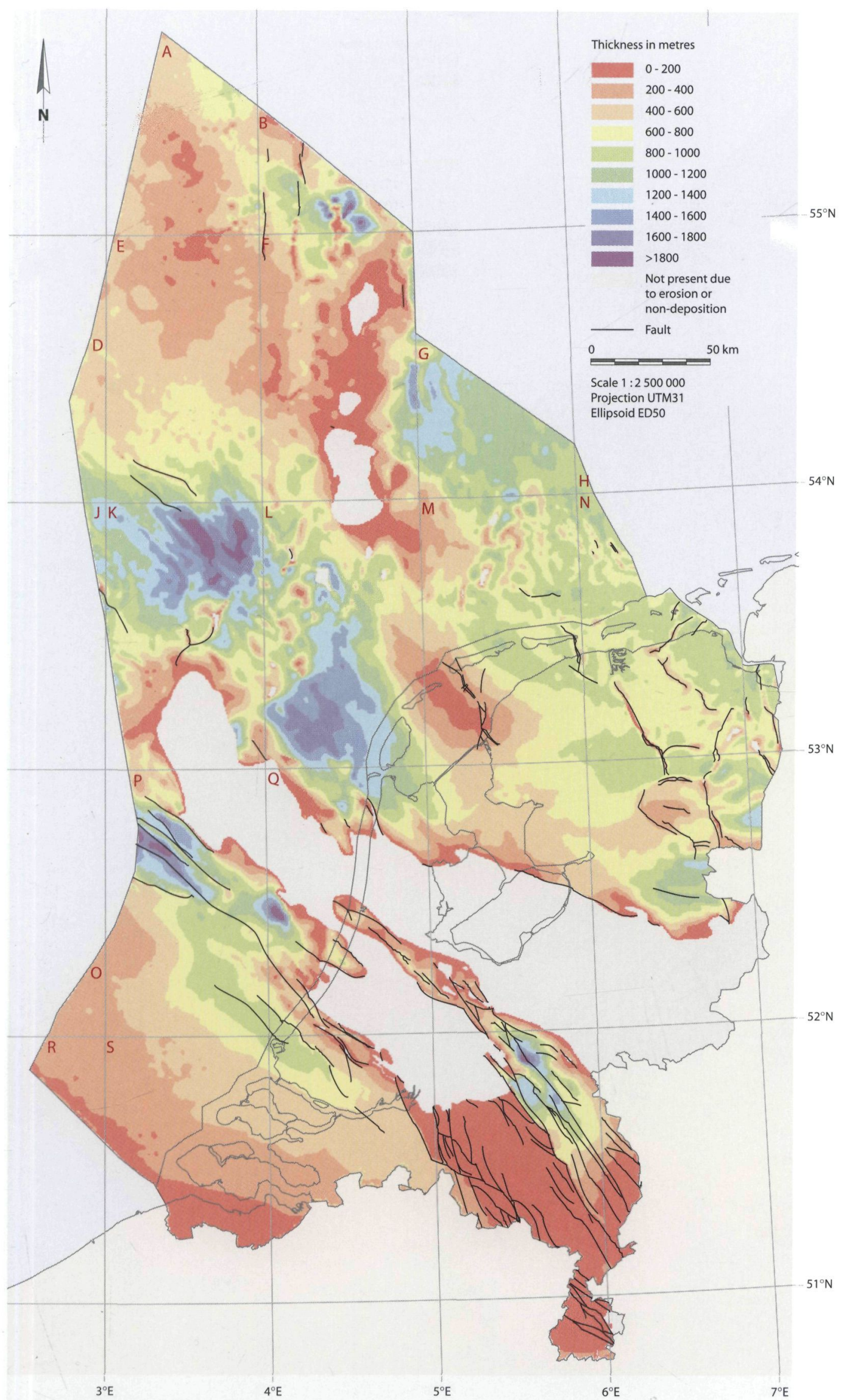

Fig. 10b. Thickness map of the Chalk Group (Late Cretaceous). 


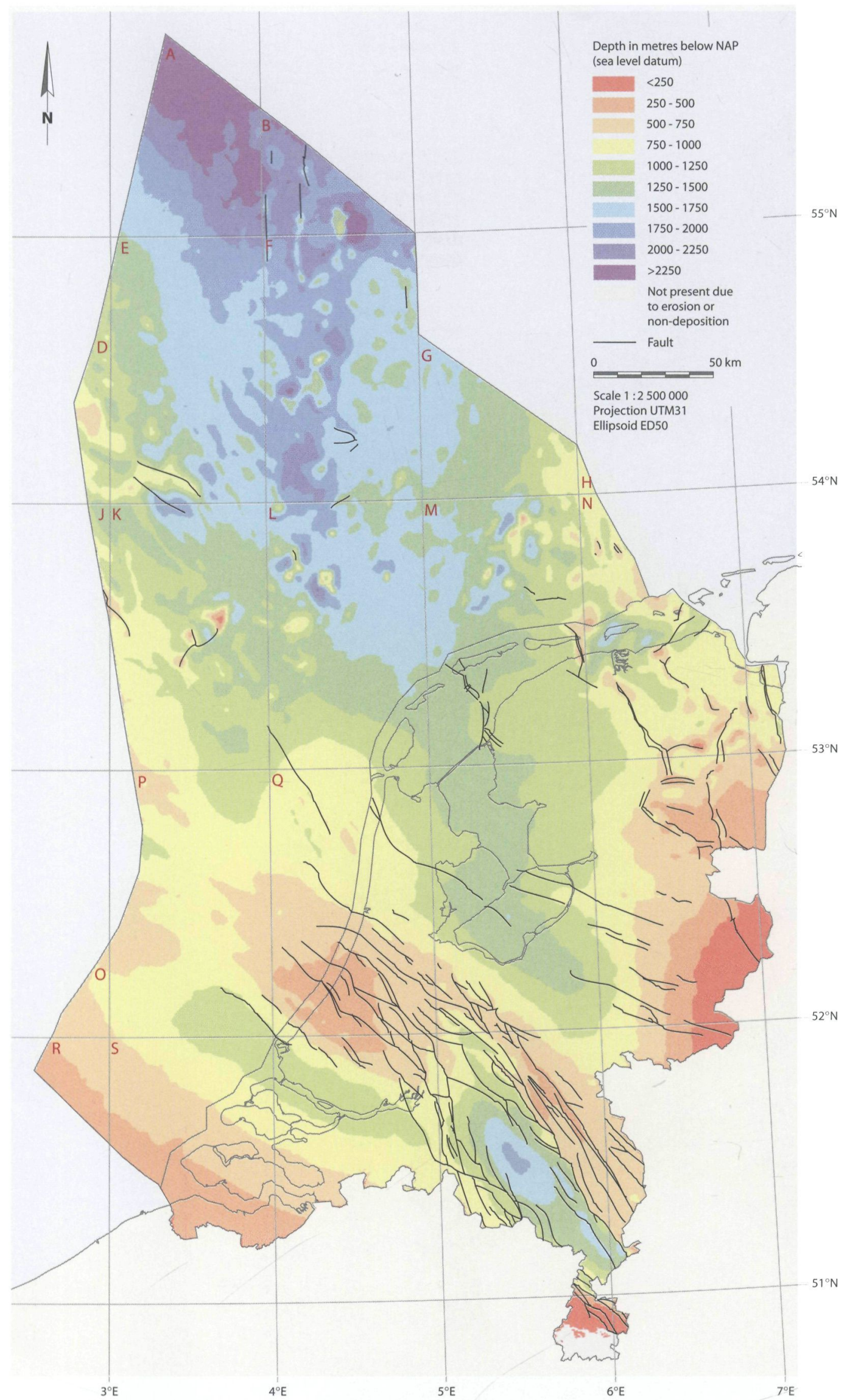

Fig. 11a. Depth map of the base of the Lower and Middle North Sea groups (Paleogene). 


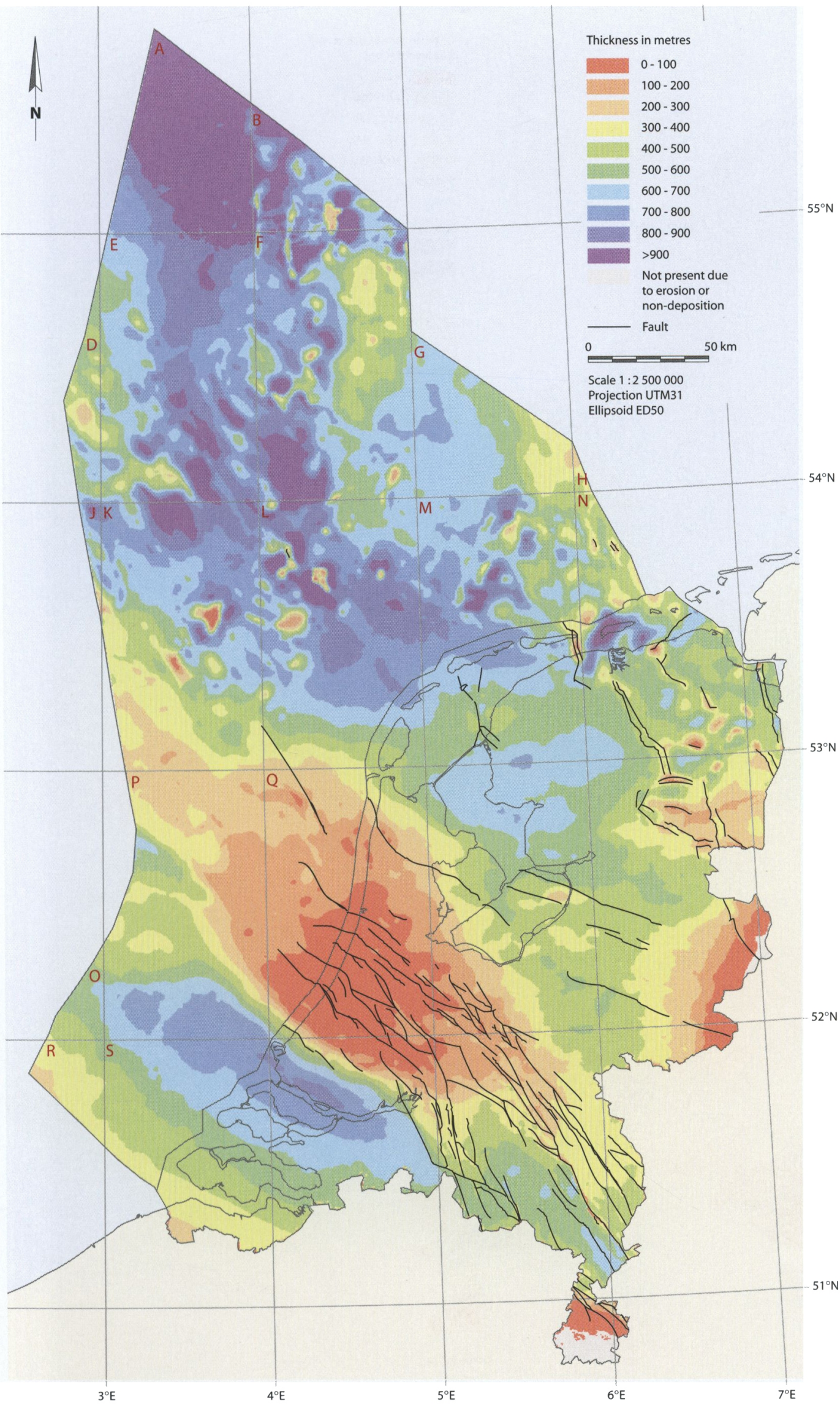

Fig. 11b. Thickness map of the Lower and Middle North Sea groups (Paleogene). 


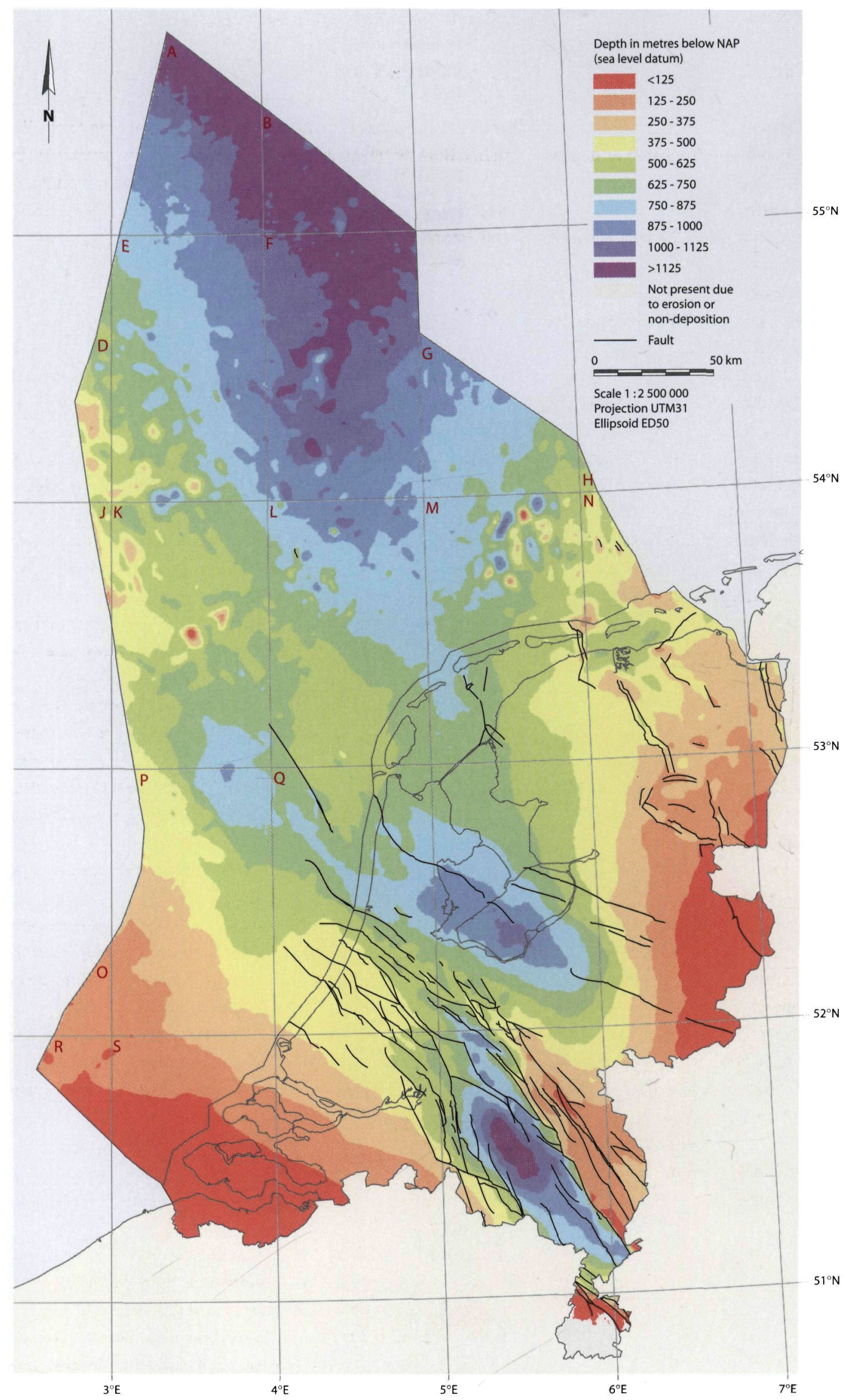

Fig. 12. Depth (and isopach) map of the Upper North Sea Group (Neogene). 


\section{North Sea Supergroup (Cenozoic)}

\section{Depth, thickness and basin development}

The base of the North Sea Supergroup outcrops in the eastern and southern parts of the Netherlands and is located at depths of more than $2000 \mathrm{~m}$ in the Dutch part of the Cenozoic North Sea Basin (NSB) (Fig. 11a). The outlines of this basin roughly coincide with the present-day North Sea (Van Adrichem Boogaert \& Kouwe, 1993 - 1997). The depth map of the base of the North Sea Supergroup shows the strong Cenozoic subsidence in the Roer Valley Graben and the offshore part of the North Sea Basin, while the Voorne Trough (VT), located on the SW-flank of the inverted part of the West Nederlands Basin (the Kijkduin High), underwent only moderate subsidence (Fig. 11a). Whilst differential subsidence of the Voorne Trough ceased at the beginning of the Miocene, the Roer Valley Graben continued to subside (Figs 12 and 11b; De Jager, 2003; Kuhlmann, 2004). 0n the other hand, subsidence of the Central Netherlands Basin, Broad Fourteens Basin and North Sea Basin accelerated during the Neogene (Fig. 12). This has also been observed by Michon et al. (2003), who conclude that the Late Eocene inversion was restricted to the southern North Sea.

\section{Structural development}

Uplift of the West Netherlands Basin resulted in depositional thinning and in erosion of the Upper Cretaceous Chalk and Paleogene clastics, as well as in local truncation of older sediments (De Jager, 2003). Strong halokinesis was active during the Paleogene in the Dutch Central Graben, Cleaver Bank High, Central Offshore Platform, Ameland Block, Hantum Fault Zone and Lower Saxony Basin (Fig. 11b). In the northern parts of the Dutch offshore subsidence has continued strongly and Neogene deposits reach a thickness of $1400 \mathrm{~m}$.

Cenozoic regional thermal subsidence of the North Sea Basin was from the Middle Eocene paralleled by the evolution of the Rhine rift system that propagated during the Oligocene northwards (Ziegler, 1988). This is evidenced by the subsidence of the Roer Valley Graben and activation of the Hantum, MidNetherlands and the Peel Boundary Fault (Figs 12 and 11b). Further growth of salt diapirs during the Cenozoic continued in the northern offshore area, as can be seen on the thickness maps of the Lower and Middle, and Upper North Sea groups (Figs 12 and 11b).

\section{Acknowledgements}

The presentation of the maps given in this paper is the result of the work of many colleagues at TNO Built Environment and Geosciences, especially within the regional mapping team. We thank Nora Witmans and Carla Elmers for their assistance in collecting, interpreting and processing the data into integrated maps and figures. The authors thank the reviewers Mark Geluk and Peter Ziegler for their technical comments to improve this manuscript.

\section{References}

De Jager, J., 2003. Inverted basins in the Netherlands, similarities and differences. Netherlands Journal of Geosciences / Geologie en Mijnbouw 82: 339-349.

De Jager, J., in press. Geological Development. In: Wong, Th.E, Batjes, D.A.J. \& De Jager, J. (eds): Geology of the Netherlands. Royal Netherlands Academy of Arts and Sciences.

Dirkzwager. J.B., 2002. Tectonic modeling of vertical motion and its near surface expression in the Netherlands, PhD thesis, VU-Amsterdam: $156 \mathrm{pp}$.

Geluk, M.C., 2005. Stratigraphy and tectonics of Permo-Triassic basins in the Netherlands and surrounding areas. PhD thesis, University of Utrecht: $171 \mathrm{pp}$.

Gradstein, F.M., Ogg, J.G. \& Smith, A.G. (eds), 2004. A geologic time scale 2004. Cambridge University Press: 589 pp.

Herngreen, G.F.W. \& Wong, Th.E., 1989. Revision of the 'Late Jurassic stratigraphy of the Dutch Central Graben. Geologie en Mijnbouw 68: 73-105.

Herngreen, G.F.W., Smit, R. \& Wong, Th.E., 1991. Stratigraphy and tectonics of the Vlieland Basin, The Netherlands. In: A.M. Spencer (ed.): Generation, accumulation and production of Europe's hydrocarbons. Special publications EAPG no. 1, 0xford University Press (0xford): 175-192.

Heybroek, P., 1974. Explanation to tectonic maps of the Netherlands. Geologie en Mijnbouw 53: 43-50.

Kuhlmann, G., 2004. High resolution stratigraphy and paleoenvironmental changes in the southern North Sea during the Neogene: An integrated study of Late Cenozoic marine deposits from the northern part of the Dutch offshore area - PhD Thesis, University Utrecht: 205 pp.

Michon, L., Van Balen R.T., Merle, O. \& Pagnier, H., 2003. The Cenozoic evolution of the Roer Valley Roft System. Tectonophysics 367: 101-126.

Mijnlieff, H., 2005. Top Pre-Permian distribution map and some thematic regional geologic maps of the Netherlands (www.nlog.nl).

Racero-Baena, A. \& Drake, S.J., 1996. Structural style and reservoir development in the West-Netherlands oil province. In: Rondeel, H.E., Batjes, D.A.J. \& Nieuwenhuizen, W.H. (eds): Geology of gas and oil under the Netherlands. Kluwer (Dordrecht): 211-227.

Remmelts, G., 1996. Salt tectonics in the southern North Sea, the Netherlands. In: Rondeel, H.E., Batjes, D.A.J. \& Nieuwenhuijs, W.H. (eds): Geology of gas and oil under the Netherlands. Kluwer (Dordrecht): 143-158.

Rijkers, R.H.B. \& Duin, E.J.Th.,1994. Crustal observations beneath the southern North Sea and their tectonic and geological implications, Tectonophysics 240: 215-224. 
Rijkers, R.H.B. \& Geluk, M.C., 1996. Sedimentary and structural history of the Texel-IJsselmeer High, The Netherlands. In: Rondeel, H.E., Batjes, D.A.J. \& Nieuwenhuizen, W.H. (eds): Geology of gas and oil under the Netherlands. Kluwer (Dordrecht): 265-284.

Scheck-Wenderoth, M. \& Lamarche, J., 2005. Crustal memory and basin evolution in Central European Basin System - new insights from a 3D structural model. Tectonophysics 397: 143-165.

Schroot, B.M. \& De Haan, H.B, 2003. An improved regional structural model of the Carboniferous of the Cleaver Bank High based on 3D seismic interpretation. In: Nieuwland, D.A. (ed): New insights into Structural interpretation, Special publications Geological Society of London 212: 23-37 TNO-NITG, 2004. Geological Atlas of the Subsurface of the Netherlands - onshore: $103 \mathrm{pp}$.

Van Adrichem Boogaert, H.A. \& Kouwe, W.F.P. (eds), 1993 - 1997. Stratigraphic nomenclature of the Netherlands, revision and update by RGD and NOGEPA, Mededelingen Rijks Geologische Dienst 50.

Van Balen, R.T., Houtgast, R.F. \& Cloetingh, S.A.P.L., 2005. Neotectonics of the Netherlands. Quaternary Science Reviews 24: 439-454.

Van Dalfsen, W., Doornenbal, J.C., Dortland, S. \& Gunnink, J.L. (this volume). A comprehensive seismic velocity model for the Netherlands based on lithostratigraphic layers, Netherlands Journal of Geosciences / Geologie en Mijnbouw 85/4: 277-292.

Van der Molen, A.S., 2004. Sedimentary development, seismic stratigraphy and burial compaction of the Chalk Group in the Netherlands North Sea area PhD thesis. University Utrecht: 175 pp.

Van Wijhe, D.H., 1987. Structural evolution of inverted basins in the Dutch offshore. Tectonophysics 137: 171-219.

Wórum, G., 2004. Modelling of faults reactivation potential and quantification of inversion tectonics in the southern Netherlands, $\mathrm{PhD}$ thesis VU Amsterdam: $152 \mathrm{pp}$.

Ziegler, P.A., 1988. Evolution of the Arctic-North Atlantic and the Western Tethys, American Association of Petroleum Geologist Memoir 43: 164-196.

Ziegler, P.A., 1990. Geological Atlas of Western and Central Europe (2nd edition). Shell Internationale Petroleum Maatschappij B.V.; Geological Society Publishing House (Bath): $239 \mathrm{pp}$ 